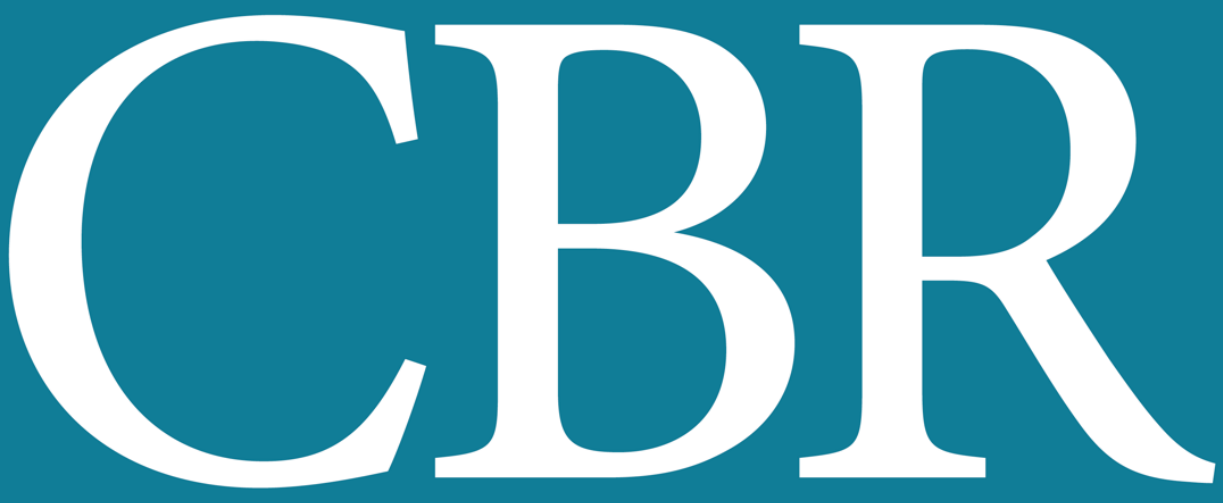

INTERNATIONAL JOURNAL OF CANCER AND BIOMEDICAL RESEARCH

https://jcbr.journals.ekb.eg

Editor-in-chief

Prof. Mohamed Labib Salem, PhD

Synergistic and chemosensitizing effects of bovine lactoferrin or muramyl dipeptide in Ehrlich solid tumor-bearing mice treated with cisplatin

Dalia S. Morsi, Mohamed L. Salem, Hany M. Ibrahim, Gamalat Y. Osman, Azza H. Mohamed and Amany E. Nofal 


\section{Welcome letter from Editor-in-Chief}

Welcome to the Int J Cancer and Biomedical Research (IJCBR)!

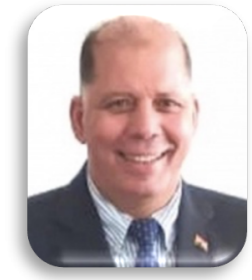

It is with great pleasure that I write this editorial to welcome you to the IJCBR. This journal provides a platform for publication of original and reviews research articles, short communications, letter to editor, thesis abstract, conference report, and case studies. These types of publication are directed at the interface of the fields of cancer and biomedical research.

The IJCBR relies on a distinguished expert of the Advisory and Editorial Board Members from the top international league covering in depth the related topics. They timely review all manuscripts and maintain highest standards of quality and scientific methodology and ethical concepts. Meanwhile, we take all possible means to keep the time of the publication process as short as possible.

I take this chance to welcome your contributions to the IJCBR and have every expectation that it will soon become one of the most respected journals in both the fields of cancer and biomedical research.

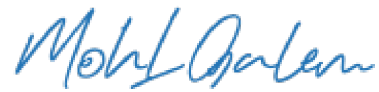

Mohamed L. Salem,

Editor in Chief 


\title{
Synergistic and chemosensitizing effects of bovine lactoferrin or muramyl dipeptide in Ehrlich solid tumor-bearing mice treated with cisplatin
}

\author{
Dalia S. Morsi ${ }^{1}$, Mohamed L. Salem ${ }^{2}$, Hany M. Ibrahim ${ }^{1}$, Gamalat Y. Osman ${ }^{1}$, Azza H. Mohamed ${ }^{1}$ and Amany \\ E. Nofal ${ }^{1}$ \\ ${ }^{1}$ Zoology Department, Faculty of Science, Menoufia University, Shibin El-Kom, Egypt \\ ${ }^{2}$ Zoology Department, Faculty of Science, Tanta University, Tanta, Egypt
}

\section{IIII}

Background: Despite the effectiveness of anti-cancer chemotherapy, it is associated with serious adverse side effects and the development of drug-resistance mechanisms. Immune dysfunction is considered one of the most serious adverse effects of anti-cancer chemotherapy, which increases the susceptibility of the patients to infection. Co-administration of immunomodulatory agents as adjuvant therapy with chemotherapy will result in better anti-tumor responses with fewer side effects. Aim: This study was designed to evaluate the ameliorative effects of bovine lactoferrin (bLF) and muramyl dipeptide (MDP) against toxicity induced by cisplatin in tumor-bearing mice. Materials and Methods: In this study, MDP or bLF was co-treated with cisplatin in mice bearing Ehrlich solid tumor (EST). Results: Cotreatment of cisplatin with MDP or bLF enhanced the anti-tumor effects of cisplatin to induce a reduction of the tumor size, proliferative capabilities of tumor cells accompanied by an elevation in the apoptotic profile of tumor cells. Moreover, cotreatments of Cisplatin with bLF or MDP reversed the Cisplatin-induced immune suppression and partially restored splenocyte proliferation, immune organ indices, hematological profile, liver and kidney functions, and histological structure. Conclusion: Both bLF and MDP were able to act as adjuvant therapy with anti-cancer chemotherapy through their abilities to enhance the chemotherapy curative effects, modulate the immune response against tumor cells, and to some extent ameliorate the adverse toxic effects of the chemotherapy.

Keywords: Cisplatin, Immunohistochemistry, Immunosuppression, Lactoferrin, Muramyl dipeptide.

Editor-in-Chief: Prof M.L. Salem, Ph.D. - Article DOI: 10.21608/JCBR.2020.32770.1047

\section{AII ARTICLE INFO}

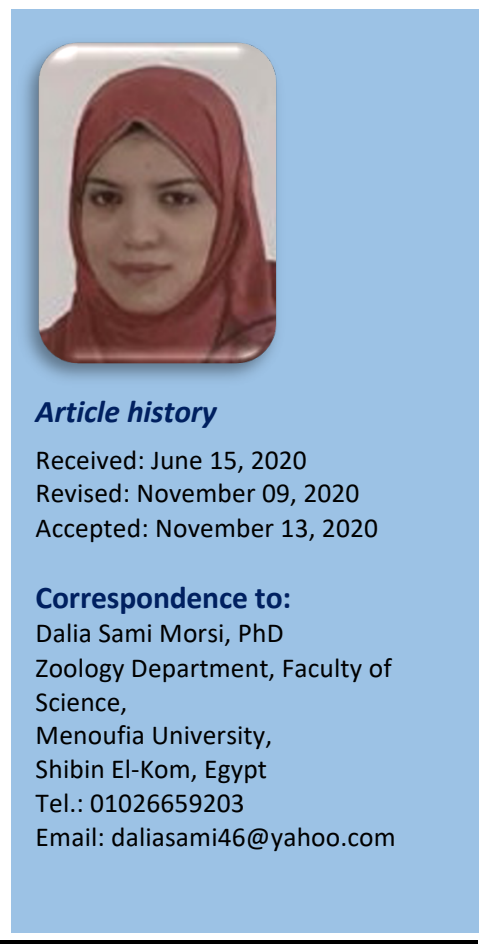

\section{INTRODUCTION}

Despite several analyses and speedy developments that occurred throughout the previous decades, most cancers still a worldwide killer. Even though superior medical technology, chemotherapy with its severe negative effects nonetheless the cornerstone of the traditional therapies of various cancers (Aston et al., 2017). Moreover, chemotherapy alone in lots of instances can't achieve passable therapeutic outcomes and, in addition to countless most cancers sorts can develop drug resistance (Park et al., 2009). Cisplatin is one of the most potent chemotherapeutic agents used for the treatment of a wide range of cancers such as ovarian, cervical, and head and neck cancers (Karadeniz et al., 2011 and Dkhil et al., 2013). Cisplatin, an anticancer drug, acts on cancer cell DNA forming adducts, causing cell cycle arrest, and thus triggering apoptosis (Eastman, 1999; Florea and Büsselberg, 2011). But cisplatin cannot distinguish cancer cells from naïve cells, lack tumor specificity, (ElSayyad et al., 2009). It exhibits many adverse side effects including immunosuppression, myelosuppression, nephrotoxicity, hepatotoxicity, ototoxicity, neurotoxicity, and cardiotoxicity (Mir et al., 2015). Subsequently, the necessity to use adjuvant therapies to promote immune responses and attenuate the 
chemotherapy toxicities has become fundamental to defeat these obstacles.

Immunomodulators are substances that elicit the immune functions to promote diseasefighting (Ibrahim et al., 2018; Abdel Ghaffar et al., 2019). The best immunomodulators come from natural sources like plants, animals, fungi, and bacteria (Mukherjee et al., 2014). Among these immunomodulators, bovine lactoferrin (bLF), is a glycosylated globular protein with a molecular weight of $78 \mathrm{kDa}$ that nearly consists of 690 amino acid residues (Baker and Baker, 2005). LF is found in many mammalian animals like camels and goats but it is more prominent in bovine milk as well as in humans (Baker and Baker, 2005). It is found in human secretions such as breast milk (especially in the colostrum), seminal fluid, uterine secretions, tears, and saliva and synthesized by different cell populations, including neutrophils, macrophages, and glandular epithelial cells, and it is mainly secreted in response to inflammatory processes (Baker and Baker, 2005; Legrand et al., 2008; Actor et al., 2009; González-Chávez et al., 2009). bLF is also known for its anti-bacterial, anti-fungal, anti-viral, antioxidant, anti-inflammatory, anti-parasitic, antiallergic, and most importantly anti-neoplastic properties (Yamauchi et al., 2006; Parhi et al., 2012, Ibrahim et al., 2020; Morsi et al., 2020). bLF exerts an immunomodulatory function on antigen-presenting cells by enhancing their activation, maturation, and migration to injured areas (Legrand et al., 2008; Actor et al., 2009; González-Chávez et al., 2009; Puddu et al., 2009; Ibrahim et al., 2019).

Muramyl dipeptide (MDP) is peptidoglycan found in the bacterial cell wall as a thin layer in a gram-negative and thick layer in gram-positive bacteria (Vollmer et al., 2008). MDP is recognized by nucleotide-binding oligomerization (NOD) domain-2, which is found in several kinds of leukocytes, mainly monocytes and macrophages. MDP signaling via NOD2 activates the leucocytes, leading to increased production of tumor necrosis factor (TNF)- $\alpha$, interleukin (IL)-1, IL-6, IL-8, IL-12, and intercellular adhesion molecule (ICAM)-1, which in order activate leucocytes to attack tumor cells (Inohara et al., 2003 and Thundimadathil, 2012).
Souvannavong et al. (1990) reported that MDP has been shown to promote the effect of other immunostimulants like interferon (IFN) $-\nu$ and to synergize with cytokines to enhance lymphocytes differentiation and proliferation.

In this study, the Ehrlich tumor-bearing mouse model was used to investigate the ameliorative effects of either bLF or MDP against cisplatininduced toxicity.

\section{MATERIALS AND METHODS}

\section{Animals}

Adult female Swiss CD1 albino mice (6-8 weeks, $28 \pm 2 \mathrm{~g})$ were obtained from the National Research Centre "NRC", Giza, Egypt. Mice were housed in polypropylene cages under controlled conditions (temperature $25 \pm 2{ }^{\circ} \mathrm{C}$ and 12 hours dark/light cycle). This work was performed after the approval of the Institutional Animal Ethical Committee, Menoufia University (approval ID: MUFS/F/IM/1/16).

\section{Cell line}

Ehrlich ascites carcinoma cells (EACs) were obtained from the National Cancer Institute, Cairo University, Egypt. EACs were maintained in female mice, and then the cells were collected using a sterile syringe and diluted with normal saline. Then the cells were counted and their viability was examined using trypan blue dye exclusion method before transportation to naïve female CD1 mice for experimentation.

\section{Chemicals}

Cisplatin (Cis), bLF, and MDP were purchased from Sigma (Sigma-Aldrich company, CA, USA), and reconstituted in $\mathrm{PBS}$ in stock solutions and stored at -80 으 until use.

\section{Experimental Design}

Forty-five female albino mice were divided into five groups ( $n=9 /$ group). All animals were weighed at the beginning and the end of the experiment; the first group was given normal saline, serving as healthy control. Then, the remaining mice were challenged with intramuscular (i.m.) injection in the right thigh of the hind limb with $2.5 \times 10^{6}$ EACs on day 0 (Noaman et al, 2008) to form Ehrlich solid tumor (EST). The mice were then treated after 10 days as follows: group (II): given normal saline, 
serving as EST control. Group (III): injected intraperitoneally "i.p." with cisplatin $(2 \mathrm{mg} / \mathrm{kg})$ (Salem et al., 2016) three doses at days 11, 13, and 15. Group (IV): treated with cisplatin as a group (III) and then orally administrated bLF $(100 \mathrm{mg} / \mathrm{kg})$ (ligo et al., 1999) for successive ten days. Group (V): treated with cisplatin as a group (III) and then injected subcutaneously "s.c." with MDP $(0.5 \mathrm{mg} / \mathrm{kg})$ three times each other day from day 11 (Bloksma et al., 1984) (Figure 1).

\section{Tumor size assessment}

After thirteen days of tumor inoculation, dimensions of the right thigh of the lower limb were measured using two-end electronic digital caliber (Switzerland), each other day till the $21^{\text {st }}$ day. Tumor size was then calculated according to Goto et al. (2000) using the formula: Tumor volume $\left(\mathrm{mm}^{3}\right)=$ Length $\times(\text { width })^{2} / 2$

\section{Sampling and cell preparation}

On day 21 , blood samples were collected from the orbital sinus. Each blood sample was divided into two tubes, one of them was mixed with EDTA anticoagulant and another was allowed to clot. Serum samples were separated by centrifugation at $4000 \mathrm{rpm}$ for 20 minutes and stored at $-80{ }^{\circ} \mathrm{C}$ until use (Alekseeva et al., 2017). The mice were then sacrificed by cervical dislocation to obtain spleens as well as liver, kidney, and right thigh muscles to be prepared for subsequent analysis.

Splenocytes single-cell suspension was prepared after RBCs lysing using ACK lysis buffer according to Ibrahim et al. (2010). Splenocytes count was determined using Trypan blue dye exclusion method. Spleen and thymus indices were assessed according to Zhao et al. (2009) using the following formula:

Organ index = organ weight (g)/ body weight (g).

\section{Histopathological examination}

Liver, kidney, and right thigh muscle tissue samples with or without tumor masses were carefully removed from all groups of the experiment and rinsed in an isotonic solution, then fixed in $10 \%$ neutral formalin. After $24 \mathrm{~h}$., tissue samples were dehydrated through ascending concentrations of ethanol and then embedded in paraplast paraffin wax. Paraffin blocks were then cut into $5 \mu \mathrm{m}$ sections and stained with haematoxylin and eosin for light microscope investigations (Suvarna et al., 2018). The sections were viewed on a light microscope (Olympus BX 41, Japan) and photographed using an Olympus digital camera.

\section{Determination of tumor cell proliferation and apoptosis using immunohistochemistry}

Tumor cell proliferation and apoptosis were determined by immunohistochemical staining of proliferating cell nuclear antigen (PCNA), anti-apoptotic protein $\mathrm{Bcl}-2$, and tumor suppressor protein p53. Paraffin sections of skeletal muscles were stained using the avidinbiotin-peroxidase method, then counterstained by Mayer's hematoxylin, cleared in xylene, and mounted in DPX, the immunohistochemical staining of each PCNA, Bcl-2, and p53 was carried out according to Arriazu et al., (2006). Slides were then examined and photographed by a light microscope (Olympus BX 41, Japan).

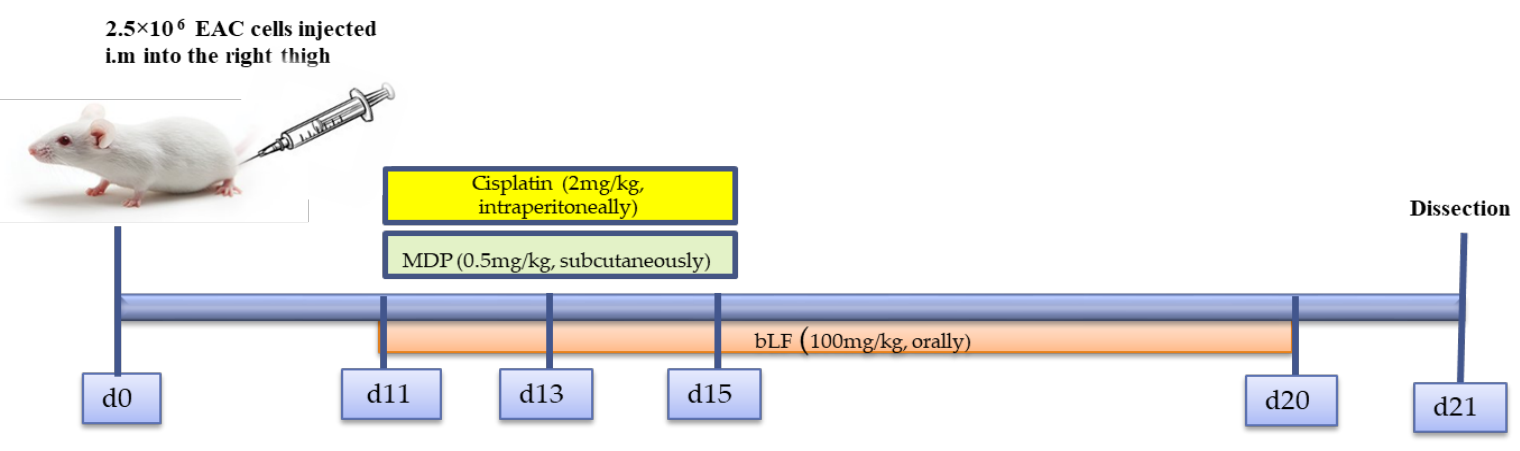

Figure 1. The applied treatment schedule 
The represented photos were photographed using an Olympus digital camera. To quantify the IHC, $1 \times 10^{3}$ cells from at least five separate tissue sections were analyzed using ImageJ software (NIH, Bethesda, MD, USA).

\section{Splenocytes immunophenotyping by flow cytometry}

Splenocytes were stained for 30 minutes at 4 으 in the dark through two panels with anti-mouse mAbs against CD4 (APC labeled, clone GK1.5), CD8 (PerCP, clone 53-6.7), CD3 (FITC labeled, clone 17A2), CD69 (PE.Cy7 labeled, clone H1. $2 F 3$ ), CD11b (APC labeled, clone M1/70) and Ly6G (FITC labeled, clone RB6-8C5). Then, splenocytes were washed with PBS twice and resuspended to $1 \times 10^{6}$ cells $/ 50 \mu$ l flow cytometry staining buffer $(0.5 \%$ bovine serum albumenPBS, $0.02 \%$ sodium azide in PBS). Surface marker expression was measured with BD FACS Canto II Flow Cytometry using BD FACS DIVA ${ }^{\text {TM }}$ software (Abdel Salam et al., 2017).

\section{Splenocytes proliferation assessment}

Splenocytes proliferative responses to mitogen Con-A were determined according to Ibrahim et al., 2013. Spleen cells were washed twice in PBS. $5 \times 10^{7}$ cells were re-suspended in PBS and stained with $5 \mu \mathrm{M}$ carboxyfluorescein diacetate succinimidyl ester (CFSE) (Bio legend, San Diego, California, USA) for eight minutes at $37^{\circ} \mathrm{C}$. Then 5 volumes of ice-cold RPMI 1640/10\% FBS was used to stop the reaction. Cells were washed 3 times in PBS. The CFSE-labeled cells were in vitro cultured in six-well plates with or without the Con-A, for 3 days. Data were analyzed using a BD FACS Canto II flow cytometer and Flow Jo software (BD Biosciences). To estimate the ConA-induced spleen cells proliferation, the percentage of un-stimulated spleen cells in the absence of the ConA was subtracted from the percentage of ConA-stimulated cells.

\section{Biochemical and Hematological Analysis}

The serum concentration of alanine aminotransferase (ALT), aspartate aminotransferase (AST), urea, and creatinine were examined using the available kits (Human, Max-Plank, Wiesbaden, Germany) according to the manufacturer instructions. Hematological measurements (red blood cells "RBCs" count, hemoglobin concentration, hematocrit value, mean corpuscular volume "MCV", mean corpuscular hemoglobin "MCH", mean corpuscular hemoglobin concentration "MCHC", white blood cell "WBCs" count, platelet count) were performed manually using blood samples mixed with EDTA previously mentioned according to (Dacie and Lewis, 1984).

\section{Statistical analysis}

The results of different groups were expressed as mean $\pm S D$. The differences between groups were evaluated using a statistical package of social science (SPSS) software for Windows, version 22. One way analysis of variance (ANOVA) followed by least significant difference (LSD) for post hoc analysis was used for multiple comparisons. Statistical significance was considered when $\mathrm{P}<0.05$.

\section{RESULTS \\ Effect of co-treatment on body weight and immune organ indices}

Mono-treatment with cisplatin significantly $(\mathrm{P}<0.05)$ decreased bodyweight, spleen, and thymus indices compared to control mice (Table 1). Co-treatments of cisplatin with bLF or MDP significantly increased both body weight and spleen index compared to the cisplatin-treated group. Cisplatin co-treatment with bLF or MDP increased thymus index without any significant difference compared to the cisplatin-treated group.

\section{Tumor Size}

Cisplatin induced a significant $\quad(\mathrm{P}<0.05)$ reduction in tumor size compared to_control mice. Co-treatments of cisplatin with bLF or MDP significantly $(P<0.05)$ decreased the tumor size compared to control mice, without any significant differences when compared to cisplatin-treated animals (Figure 2).

\section{Histopathological observations}

Liver: Sections of naïve mice liver revealed that the polyhedral round hepatocytes with eosinophilic cytoplasm and round basophilic nucleus radially arranged in hepatic strands which are separated by irregular blood sinusoids. Examination of the liver of control mice displayed apparent signs of degenerative changes, such as cytoplasmic vaculation of the 
Table 1. Effect of Cisplatin co-treatment with bLF or MDP on body weight, spleen, and thymus indices in mice.

\begin{tabular}{lccc}
\hline Groups & Bodyweight (g) & Spleen Index (\%) & Thymus Index (\%) \\
\hline Naïve & $32.4 \pm 1.14$ & $4.68 \pm 0.23$ & $1.21 \pm 0.22$ \\
Control & $30.8 \pm 0.83$ & $6.04 \pm 0.38$ & $3.15 \pm 0.36$ \\
Cisplatin & $18.9 \pm 1.3^{*}$ & $3.52 \pm 0.37^{*}$ & $0.9 \pm 0.03^{*}$ \\
Cisplatin + bLF & $21.9 \pm 0.68^{* \#}$ & $5.56 \pm 0.35^{\#}$ & $1.55 \pm 0.15^{*}$ \\
Cisplatin + MDP & $30.2 \pm 0.83^{\#}$ & $5.31 \pm 0.41^{\#}$ & $1.15 \pm 0.11^{*}$ \\
\hline
\end{tabular}

Data were presented as mean $\pm \mathrm{SD}, \mathrm{n}=5 .{ }^{*} P<0.05$ indicates a significant difference compared to the Control group. ${ }^{\#} P<0.05$ indicates a significant difference compared to Cisplatin- treated mice. bLF: bovine lactoferrin; MDP: muramyl dipeptide.

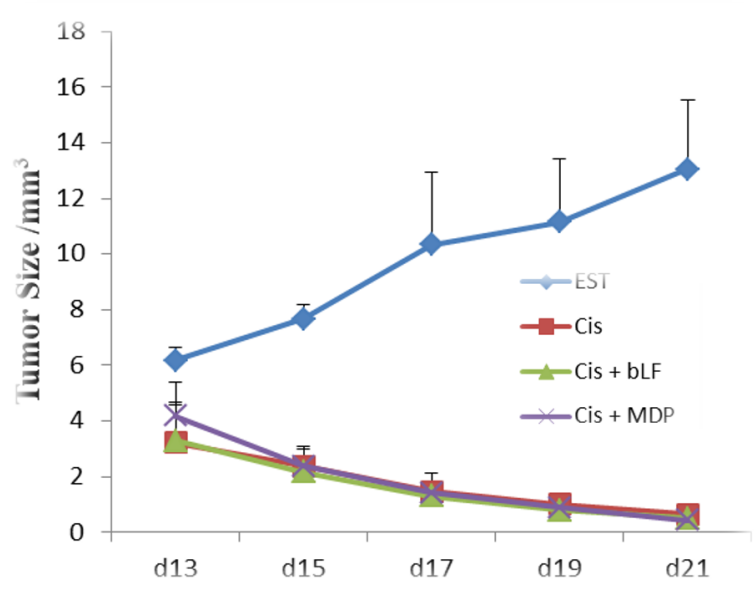

Figure 2. The effect of Cisplatin co-treatment with bLF or MDP on tumor size. Data were expressed as the mean \pm $\mathrm{SD}, \mathrm{n}=5$. Statistical difference was calculated with an ANOVA and follow-up test (LSD). ${ }^{*} P<0.05$ indicated a significant difference compared to the control group. $\# P<$ 0.05 indicated a significant difference compared to Cisplatin- treated mice.

hepatocytes with apoptotic nuclei and infiltration of a variable cell population of polygonal-shaped tumor cells with hyperchromatic nuclei beside an enlarged branch of the portal vein and bile ductule. Liver sections of EST-bearing mice treated with cisplatin were revealed marked cytoplasmic vacuolation of hepatocytes, number of binucleated cells, and congested portal veins, while co-treatments with bLF or MDP exhibited partially an improvement in liver structure (Figure 3).

Kidney: kidneys of naïve mice showed the normal structure of renal glomeruli with intact Bowman's capsule and renal tubules which are lined with epithelial cells. Control mice exhibited degeneration, shrinkage, atrophy, and infiltration of inflammatory cells into the glomeruli, degeneration of epithelial cells of some renal tubules, and inflammatory leucocytic infiltration. Kidney sections of ESTbearing mice treated with cisplatin were exerted nephrotoxic effects, as edematous spaces, enlarged degenerated glomeruli with infiltrated inflammatory cells, and wider lumen of renal tubules with exfoliated degenerated epithelium. Fortunately, cisplatin co-treatment with bLF or MDP ameliorated the nephrotoxicity induced by cisplatin as they showed a nearly normal structure with several infiltrated inflammatory cells inside the glomeruli and between the renal tubules (Figure 4).

Skeletal muscle: Histological examination of longitudinal sections of thigh muscles obtained from naïve mice showed the normal structure of muscle fibers arranged into bundles and separated by perimysium connective tissue. Each muscle fiber is polygonal with peripheral pale oval nuclei and surrounded by endomysium connective tissue. Longitudinal sections of thigh muscle of control mice showed that the remaining skeletal muscles were completely replaced and infiltrated by polygonal-shaped tumor cells with hyperchromatic nuclei and abundant eosinophilic cytoplasm, edema, irregular muscle fiber structure, pale staining degenerated myocytes with homogenized appearance without striations and wide gaps between them. The skeletal muscles of ESTbearing mice treated with cisplatin showed marked disruption and irregular fibers structure with nuclear clumps, edema, and most myofibers were replaced by fibro-adipose tissue as large fat vacuoles (macrosteatosis) or very small fat droplets (microsteatosis). The striations in the edematous area were partially disappeared and the myocytes had mild swellings with eosinophilically stained cytoplasm. Fortunately, cisplatin co-treatment with bLF or MDP showed an improvement in muscular strands with slight abnormalities (Figure 5). 


\section{Tumor cells proliferation and apoptosis}

Table 2 shows that tumor cells in control mice exhibited the highest level $(19.79 \pm 0.3 \%)$ of the proliferation marker PCNA expression. The current study revealed that cisplatin monotreatment significantly $(\mathrm{P}<0.05)$ suppressed PCNA expression in tumor cells $(6.98 \pm 0.07 \%)$. Interestingly, cisplatin co-treatment with bLF or MDP significantly $(\mathrm{P}<0.05)$ reduced PCNA expression $5.59 \pm 0.1 \%$ and $5.74 \pm 0.1 \%$ respectively when compared to both control mice and those mono-treated with cisplatin (Figure 6). Furthermore, it was clear that tumor cells in control animals showed immunohistochemical overexpression of the anti-apoptotic Bcl-2 protein (19.45 $\pm 0.25 \%$ ). Cisplatin mono-treatment and co-treatments with bLF or MDP significantly $(P<0.05)$ succeeded to suppress the anti-apoptotic Bcl-2 protein expression $3.0 \pm 0.05 \%, 2.07 \pm 0.48 \%$, and $2.3 \pm 0.2 \%$ respectively, compared to control mice and cisplatin-treated mice (Figure 7). Moreover, cisplatin mono-treatment significantly $(P<0.05)$ elevated the proapoptotic p53 expression level $(18.73 \pm 0.25 \%)$ compared to control mice, also, cisplatin cotreatment with bLF or MDP significantly $(P<0.05)$ increased the pro-apoptotic p53 expression $18.7 \pm 0.4 \%$ and $20.95 \pm 0.05 \%$, respectively compared to both control mice and those mono-treated with cisplatin (Figure 8).

\section{Effect of co-treatment on splenocytes proliferation}

Cisplatin mono-treatment significantly $(P<0.05)$ decreased the rate of splenocytes proliferation compared to control mice. Co-treatment with bLF or MDP significantly $(P<0.05)$ restored splenocytes proliferation rate compared to control and cisplatin-treated mice (Figure 9).

\section{Effect of co-treatment on splenocytes immunophenotypic analysis}

Cisplatin mono-treatment induced nonsignificant changes in the percentages of $\mathrm{CD}^{+} \mathrm{CD}^{+}, \mathrm{CD}^{+} \mathrm{CD}^{+}$and $\mathrm{CD}^{+}{ }^{+} \mathrm{CD} 8^{+} \mathrm{CD} 69^{+}$ compared to control_mice. On the other hand, it resulted in a significant $(P<0.05)$ decrease in the percentages of $\mathrm{CD}^{+} \mathrm{CD} 4^{+} \mathrm{CD} 69^{+}$compared to control mice. Co-treatments of cisplatin with either bLF or MDP significantly $(P<0.05)$ and partially improved the percentages of $\mathrm{CD}^{+} \mathrm{CD}^{+}, \quad \mathrm{CD}^{+}{ }^{+} \mathrm{CD} 4^{+} \mathrm{CD}^{+} 9^{+}$and $\mathrm{CD}^{+} \mathrm{CD}^{+} \mathrm{CD} 9^{+}$compared to control mice and cisplatin-treated mice. Moreover, those cotreatments minimally increased the percentage of $\mathrm{CD}^{+} \mathrm{CD}^{+}$cells without any significant difference compared to control mice and those treated with cisplatin. Furthermore, cotreatments of cisplatin with bLF significantly $(P<0.05)$ alleviated the percentage of $\mathrm{CD}_{11 b^{+} \mathrm{Ly} \mathrm{G}^{+}}$spleen cells compared to control mice. Cisplatin co-treatment with MDP showed significant $\quad(\mathrm{P}<0.05) \quad$ improvement in CD $11 b^{+}{ }^{2}{ } 6 G^{+}$spleen cells percentage when compared to cisplatin-treated mice. Ultimately, cisplatin co-treatment with bLF or MDP succeeded to partially restore the percentages of investigated immune cells when compared to cisplatin mono-treatment (Table 3).

\section{Biochemical and Hematological changes}

Tumor development was correlated with alterations in liver and kidney functions as approved by a marked rise in serum AST, ALT, urea, and creatinine concentrations (Table 4). Cisplatin mono-treatment induced significant $(\mathrm{P}<0.05)$ elevation in serum ALT, AST, urea, and creatinine levels as compared to control mice.

Co-treatments of cisplatin with bLF or MDP caused a significant $(P<0.05)$ decrease in the AST, ALT, urea, and creatinine as compared to control and cisplatin-treated animals. Fortunately, cisplatin co-treatment with bLF or MDP tend to attain significant $(P<0.05)$ amelioration in serum urea and creatinine levels toward normal values as compared to the cisplatin-treated group.

Cisplatin mono-treatments significantly $(P<0.05)$ reduced total RBCs, WBCs, platelets count, relative lymphocytes, hemoglobin concentration, and packed cell volume when compared with control mice. On the other side, cisplatin mono-treatment induced a significant $(P<0.05)$ increase in relative granulocytes as compared to control mice (Table 5).

Cisplatin co-treatment with bLF resulted in significant $(P<0.05)$ improvement in RBCs, WBCs, platelets count, relative lymphocytes, relative granulocytes, and hemoglobin concentration when compared to control mice 
Table 2. Effect of Cisplatin co-treatment with bLF or MDP on PCNA, Bcl-2, and p53 immunohistochemical expression in tumor mass of different groups.

\begin{tabular}{llll}
\hline Groups & PCNA \% & Bcl-2 \% & P53 \% \\
\hline Control & $19.79 \pm 0.3$ & $19.45 \pm 0.25$ & $0.23 \pm 0.07$ \\
Cisplatin & $6.98 \pm 0.07^{*}$ & $3.0 \pm 0.05^{*}$ & $18.73 \pm 0.25^{*}$ \\
Cisplatin + bLF & $5.59 \pm 0.1^{* \#}$ & $2.07 \pm 0.48^{* \#}$ & $18.7 \pm 0.4^{*}$ \\
Cisplatin + MDP & $5.74 \pm 0.1^{* \#}$ & $2.3 \pm 0.2^{* \#}$ & $20.95 \pm 0.05^{* \#}$
\end{tabular}

Data were presented as mean $\pm \mathrm{SD}, \mathrm{n}=5$. $^{*} P<0.05$ indicates a significant difference compared to the control group. ${ }^{\#} P<0.05$ indicates a significant difference compared to Cisplatin- treated mice. bLF: bovine lactoferrin; MDP: muramyl dipeptide; PCNA: Proliferating cell nuclear antigen; Bcl-2: B-cell lymphoma-2.

Table 3. Effect of Cisplatin co-treatment with bLF or MDP on splenocytes immuno-phenotyping in EST-bearing mice.

\begin{tabular}{|c|c|c|c|c|c|}
\hline Groups & $\mathrm{CD}^{+}{ }^{+} \mathrm{CD} 4+(\%)$ & $\mathrm{CD3}^{+} \mathrm{CD}^{+}+(\%)$ & $\mathrm{CD}^{+}{ }^{+} \mathrm{CD} 8+{ }^{+} \mathrm{CD} 69^{+}(\%)$ & $\mathrm{CD}^{+}{ }^{+} \mathrm{CD} 4^{+}{ }^{-C D 69}{ }^{+}(\%)$ & CD11b+Ly6G+ (\%) \\
\hline Naïve & $37.2 \pm 0.56$ & $14.6 \pm 2.4$ & $3.7 \pm 1.24$ & $0.077 \pm 0.051$ & $0.24 \pm 0.055$ \\
\hline Control & $16.5 \pm 2.1$ & $8.32 \pm 1.2$ & $33.07 \pm 2.8$ & $16.3 \pm 2.4$ & $16.05 \pm 3.2$ \\
\hline Cisplatin & $13.8 \pm 2.3$ & $7.4 \pm 0.08$ & $31.2 \pm 4.4$ & $5 \pm 0.4^{*}$ & $2.5 \pm 0.17^{*}$ \\
\hline Cisplatin + bLF & $17.85 \pm 2.4^{*}$ & $8.42 \pm 1.8$ & $24 \pm 3.1^{* \#}$ & $2.2 \pm 0.48^{* \#}$ & $1.5 \pm 0.36^{*}$ \\
\hline Cisplatin + MDP & $17.15 \pm 1.02^{*}$ & $10.1 \pm 2.9$ & $4.4 \pm 0.61^{* \#}$ & $0.18 \pm 0.06^{* \#}$ & $0.12 \pm 0.05^{* \#}$ \\
\hline
\end{tabular}

Data were presented as mean $\pm S D, n=4 .{ }^{*} P<0.05$ indicates a significant difference compared to the control group. ${ }^{\sharp} P<0.05$ indicates a significant difference compared to Cisplatin- treated mice. bLF: bovine lactoferrin; MDP: Muramyl dipeptide.

Table 4. Biochemical changes of EST-bearing mice co-treated with Cisplatin and bLF or MDP.

\begin{tabular}{lllll}
\hline Groups & AST (IU/L) & ALT (IU/L) & Urea $(\mathrm{mg} / \mathrm{dL})$ & Creatinine $(\mathrm{mg} / \mathrm{dL})$ \\
\hline Naïve & $63.28 \pm 8.3$ & $31.3 \pm 0.81$ & $42.6 \pm 3.72$ & $0.82 \pm 0.26$ \\
Control & $214.54 \pm 20.13$ & $121.78 \pm 9.47$ & $45.68 \pm 2.4$ & $0.91 \pm 0.1$ \\
Cisplatin & $434.8 \pm 72.28^{*}$ & $145.78 \pm 2.9^{*}$ & $60.4 \pm 11.3^{*}$ & $2.47 \pm 0.42^{*}$ \\
Cisplatin + bLF & $380.8 \pm 20.9^{* \#}$ & $188.3 \pm 1.78^{* \#}$ & $37.2 \pm 4.59^{* \#}$ & $1.38 \pm 0.33^{* \#}$ \\
Cisplatin + MDP & $380.84 \pm 24.7^{* \#}$ & $185.7 \pm 4.64^{* \#}$ & $42.24 \pm 3.69^{\#}$ & $1.5 \pm 0.58^{* \#}$ \\
\hline
\end{tabular}

Data were presented as mean $\pm S D, n=5 .{ }^{*} P<0.05$ indicates a significant difference compared to the control group. $\# P<0.05$ indicates a significant difference compared to Cisplatin- treated mice. bLF: bovine lactoferrin; MDP: muramyl dipeptide; AST: aspartate aminotransferase; ALT: alanine aminotransferase.

Table 5. Hematological changes of EST-bearing mice co-treated with cisplatin and bovine lactoferrin or muramyl dipeptide.

\begin{tabular}{|c|c|c|c|c|c|}
\hline & Naïve & Control & Cisplatin & Cisplatin + bLF & Cisplatin + MDP \\
\hline $\operatorname{RBC}\left(10^{6} / \mathrm{mm}^{3}\right)$ & $4.58 \pm 0.52$ & $4.12 \pm 0.25$ & $3.38 \pm 0.34^{*}$ & $3.6 \pm 0.47^{*}$ & $4.1 \pm 0.33^{\#}$ \\
\hline Hemoglobin (g/dl) & $12.38 \pm 1.6$ & $11.5 \pm 0.8$ & $9.32 \pm 0.97^{*}$ & $9.58 \pm 1.3^{*}$ & $11.5 \pm 0.93^{\#}$ \\
\hline Hematocrit (\%) & $38.6 \pm 4.5$ & $34.4 \pm 2.4$ & $28.6 \pm 2.8^{*}$ & $24.4 \pm 4.03^{*}$ & $35 \pm 2.9^{\#}$ \\
\hline $\operatorname{MCV}(f \mathrm{fl}$ & $31.24 \pm 1.7$ & $29.48 \pm 0.91$ & $30.7 \pm 1.7$ & $29.8 \pm 0.61$ & $30.2 \pm 0.26$ \\
\hline MCH (pg) & $27.01 \pm 1.54$ & $27.9 \pm 1.66$ & $27.61 \pm 0.73$ & $26.6 \pm 0.89$ & $28.1 \pm 0.77$ \\
\hline MCHC (\%) & $32.04 \pm 1.7$ & $33.42 \pm 0.37$ & $32.6 \pm 1.7$ & $33.4 \pm 0.65$ & $33 \pm 0.0$ \\
\hline Platelets $\left(10^{3} / \mathrm{mm}^{3}\right)$ & $395 \pm 29.7$ & $474 \pm 56.05$ & $297 \pm 53.3^{*}$ & $476 \pm 131.5^{\#}$ & $361 \pm 58.1^{* \#}$ \\
\hline WBCs $\left(10^{3} / \mathrm{mm}^{3}\right)$ & $7.06 \pm 3.1$ & $8.06 \pm 3.0$ & $4.65 \pm 0.97^{*}$ & $10.8 \pm 2.01^{* \#}$ & $10.52 \pm 0.95^{\#}$ \\
\hline Granulocytes (\%) & $35.3 \pm 4.1$ & $57 \pm 2.6$ & $75.6 \pm 1.14^{*}$ & $72 \pm 4.6^{*}$ & $52.2 \pm 7.29^{\#}$ \\
\hline Lymphocytes (\%) & $60 \pm 4.0$ & $39 \pm 1$ & $19 \pm 2.2^{*}$ & $24 \pm 4.6^{*}$ & $42 \pm 6.63^{\#}$ \\
\hline Monocytes (\%) & $5.3 \pm 1.15$ & $4 \pm 0.1$ & $5.4 \pm 1.6$ & $4.8 \pm 1.7$ & $5.8 \pm 1.48$ \\
\hline
\end{tabular}

Data were presented as mean $\pm \mathrm{SD}, \mathrm{n}=5 .{ }^{*} P<0.05$ indicates a significant difference compared to the control group. ${ }^{\#} P<$ 0.05 indicates a significant difference compared to Cisplatin- treated mice. bLF: bovine lactoferrin; MDP: muramyl dipeptide; RBCs: red blood cells; MCV: mean corpuscular volume; $\mathrm{MCH}$ : mean corpuscular hemoglobin; MCHC: mean corpuscular hemoglobin concentration; WBCs: white blood cells. 


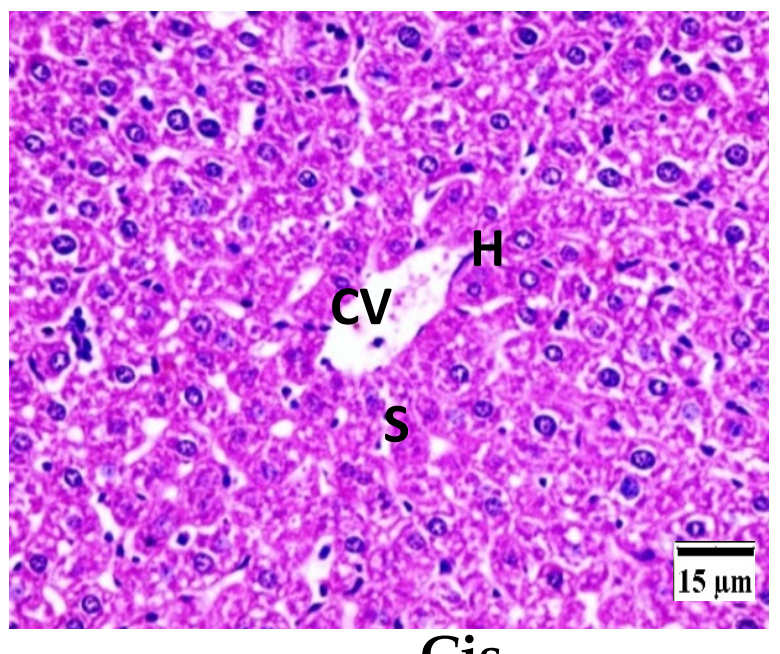

\section{Control}
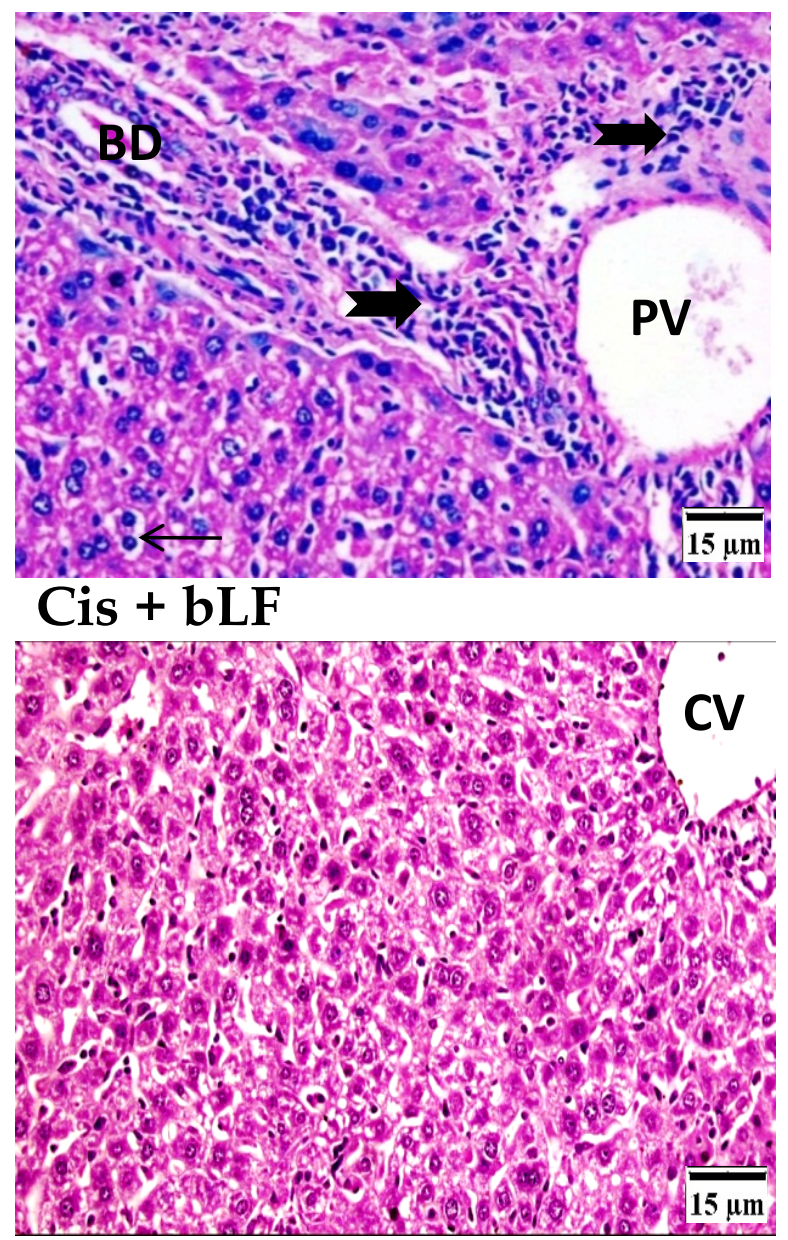

\section{Cis}

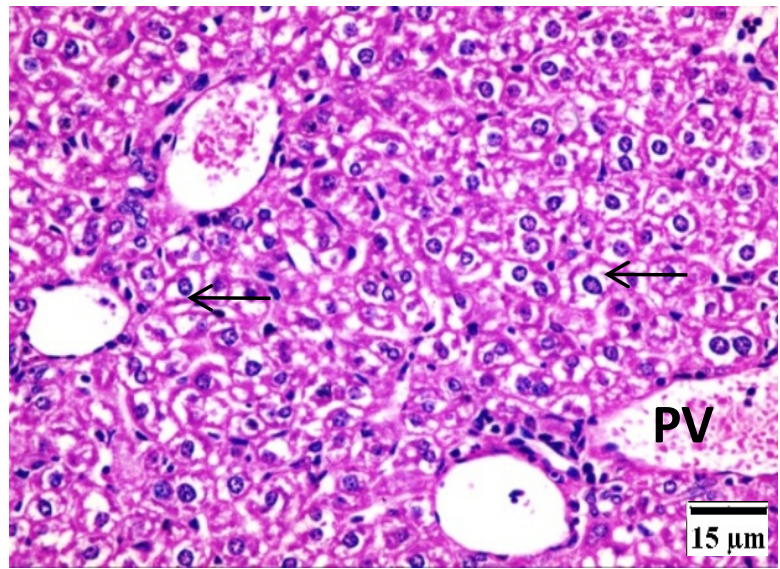

\section{Cis + MDP}

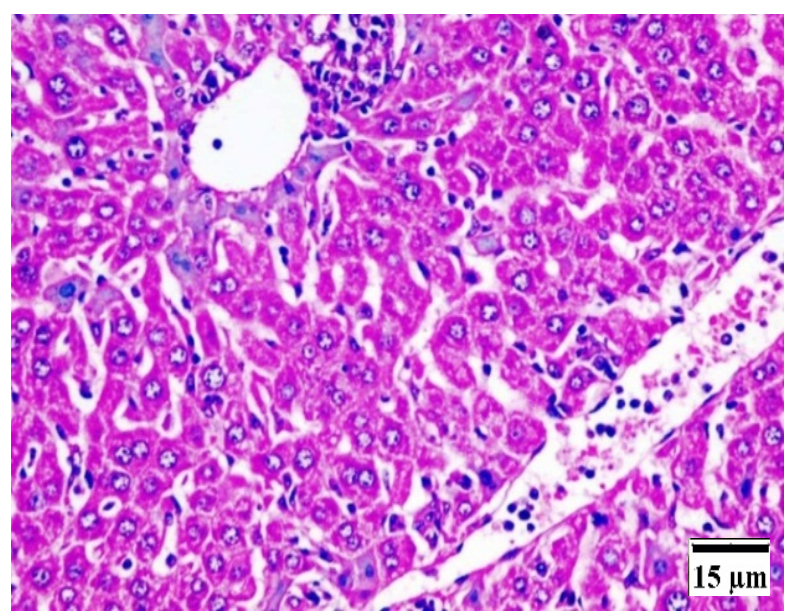

Figure 3. Light micrograph of liver sections Naïve mice showing normal hepatic structure; hepatocytes (H), central vein (CV), blood sinusoids (S), control mice showing infiltration of leukocytes mixed with tumor cells (thick arrows) around the enlarged branch of the portal vein (PV) and bile ductule (BD), cytoplasmic vaculation of hepatocytes (thin arrow); mice treated with cisplatin exhibiting marked cytoplasmic vacuolization of hepatocytes with several binucleated cells (arrows) ), and congestion of portal vein with eroded lining (PV); co- treatments (Cisplatin + bLF) and (Cisplatin + MDP), both showing an improvement in liver structure, (H\&E, $\times 400)$. 


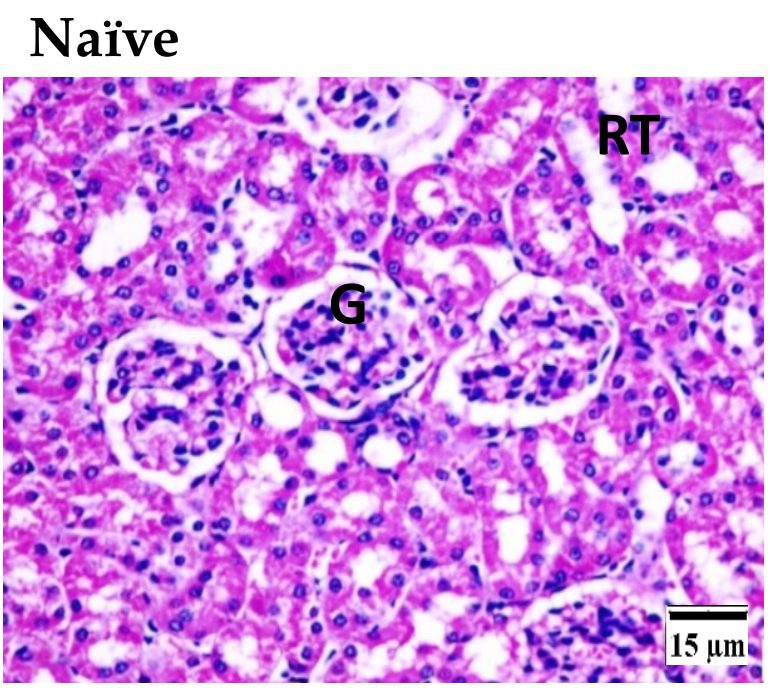

\section{Control}

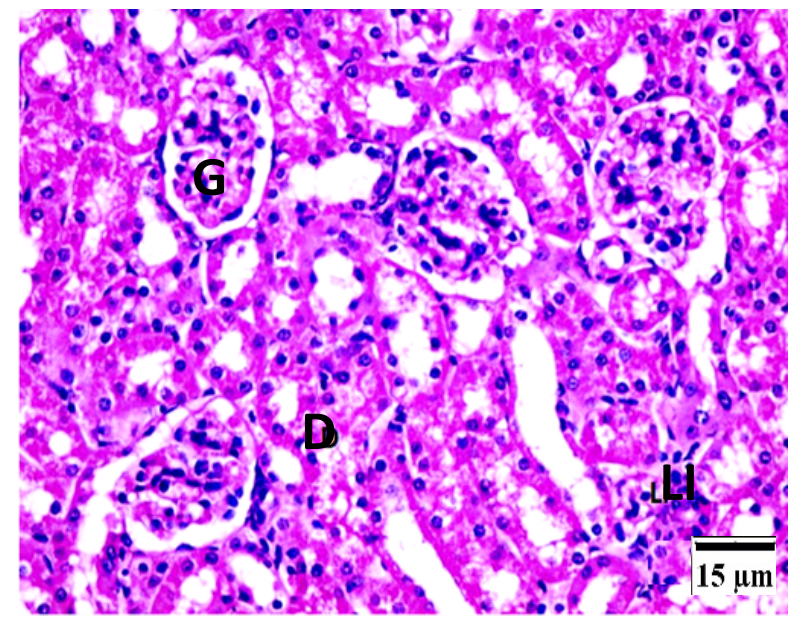

\section{Cis + bLF}

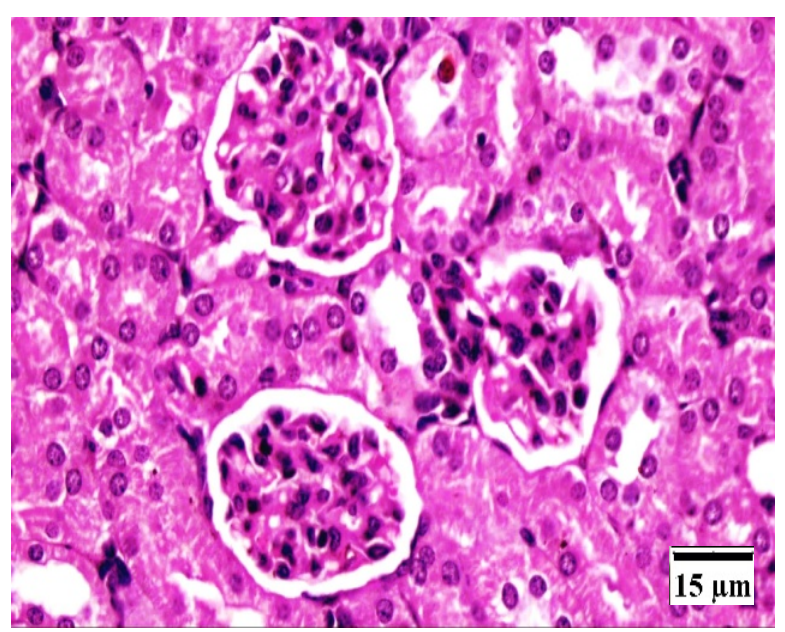

\section{Cis}

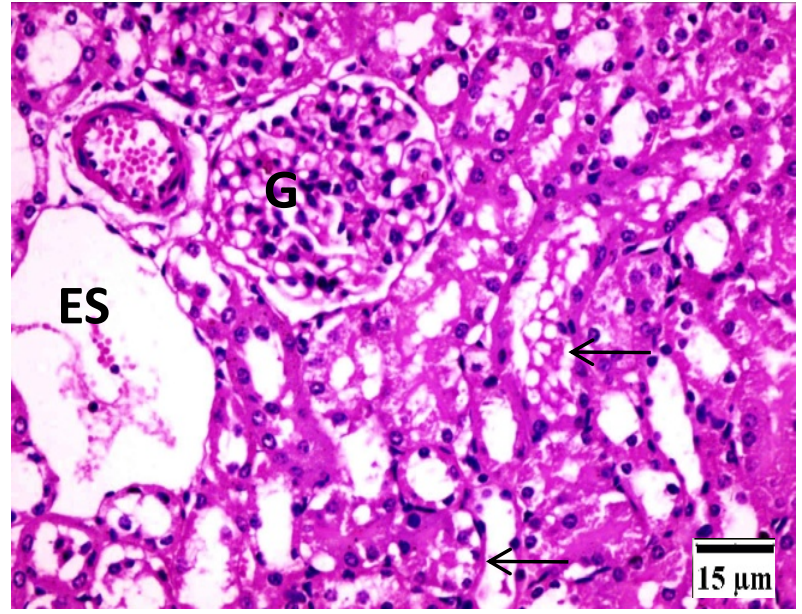

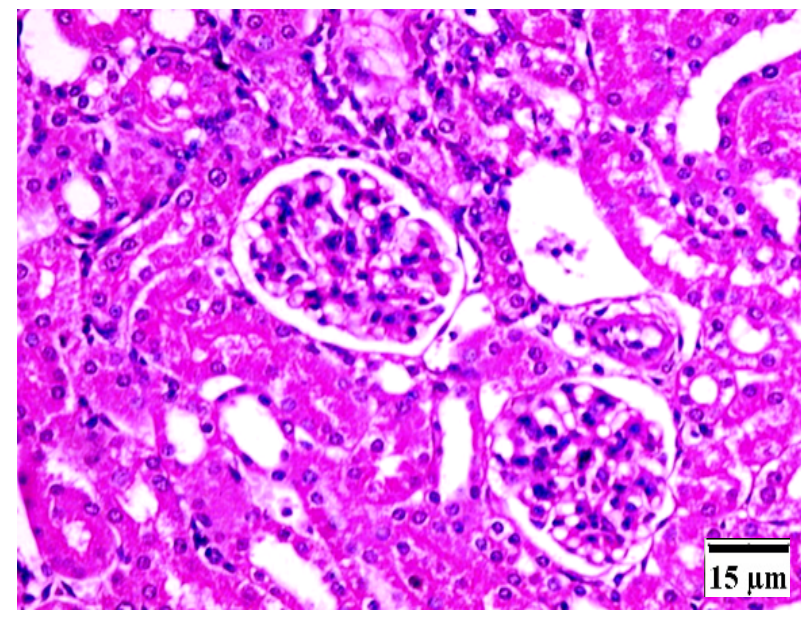

Figure 4. Light micrograph of kidney sections Naïve mice showing the basic normal structure; Bowman's capsule with glomerulus (G) and renal tubules (RT); control mice showing degeneration of glomeruli (G) and epithelial cells of some renal tubules (D), and leucocytic infiltration (Li); mice treated with Cisplatin exhibiting edematous spaces (ES), enlarged fragmented glomeruli (G) and cytoplasmic vacuolation of the damaged renal tubule with pyknotic nuclei (arrows); co- treatments (Cisplatin + bLF) and (Cisplatin + MDP) both showing a nearly normal structure with several infiltrated inflammatory cells inside the glomeruli and between the renal tubules, (H\&E, $\times 400)$. 


\section{Naïve}

\section{Control}

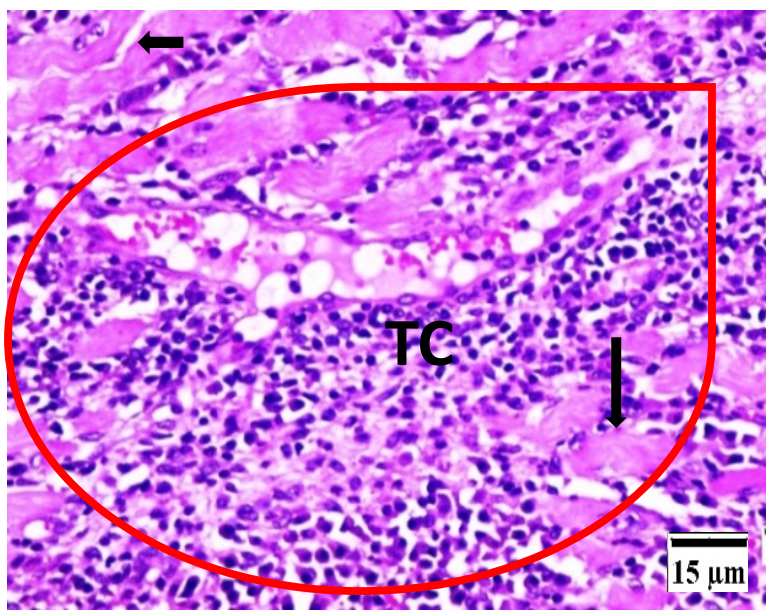

\section{Cis + bLF}

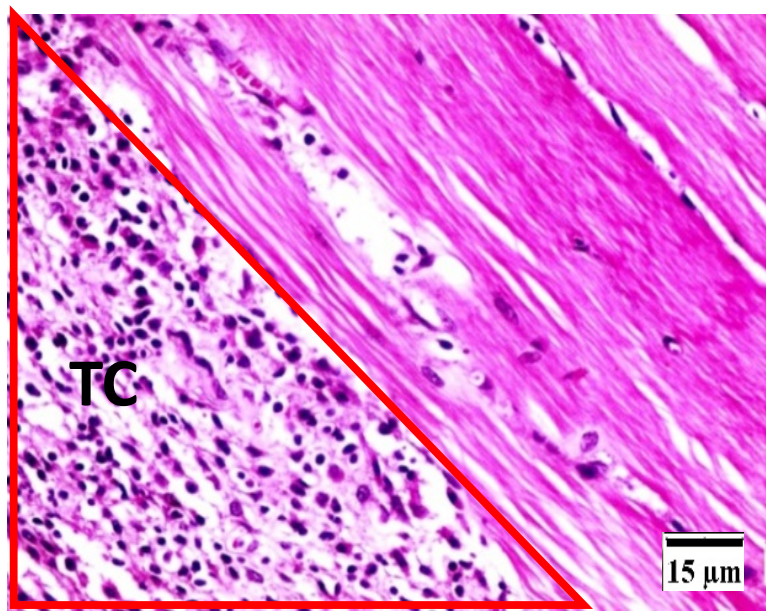

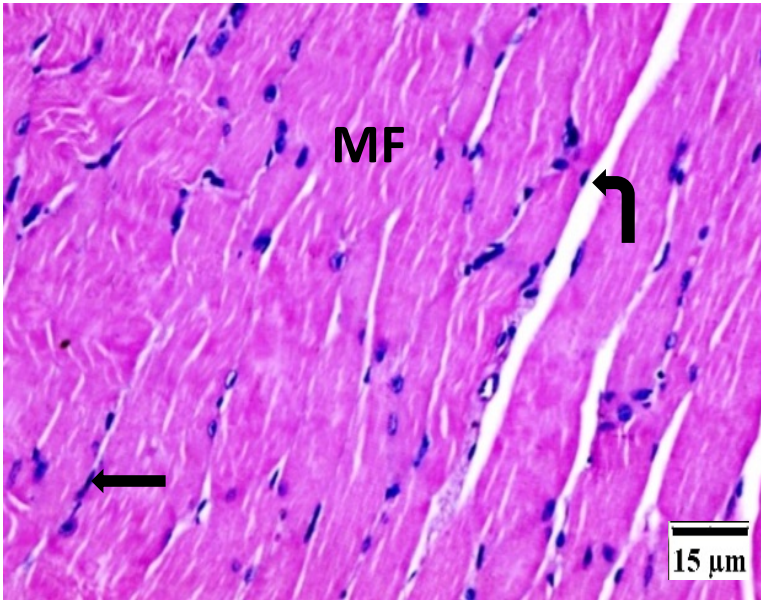

Cis

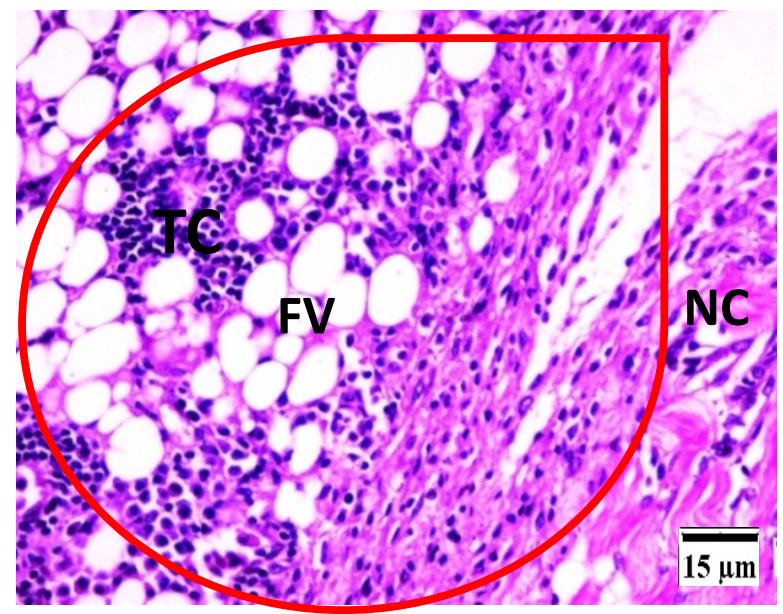

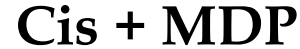

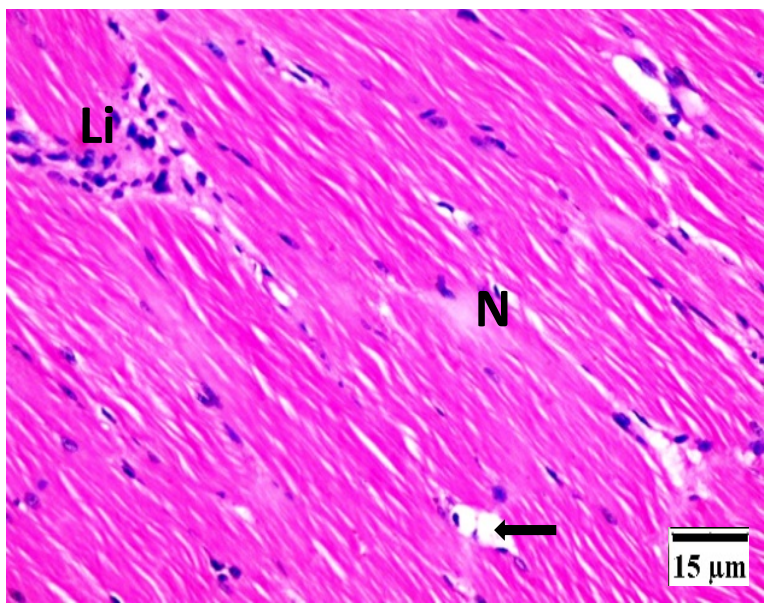

Figure 5. Longitudinal sections in the skeletal muscle Naïve mice with the normal architecture of muscle fibers, peripheral nuclei (arrow) situated in the side of the myofiber (MF) by narrow intercellular endomysium (curved arrow); sections of control mice variable cell population consisting of polygonal-shaped tumor cells with hyperchromatic nuclei (TC), and irregular muscle fiber structure with pale staining degenerated myocytes (arrows); mice treated with Cisplatin exhibiting marked tumor area (TC) with irregular muscle fiber structure (arrow) with nuclear clumps (NC), and fatty vacuoles (FV); the co-treatment (Cisplatin + bLF) showing the reappearance of normal muscle structure with the remaining of tumor cells (TC); the co-treatment (Cisplatin + MDP) showing an improvement in muscle structure with slight leucocytic infiltration (Li), dilation of blood vessels (arrow), and few necrotic myocytes (N), (H\&E, x400). 


\section{Control}

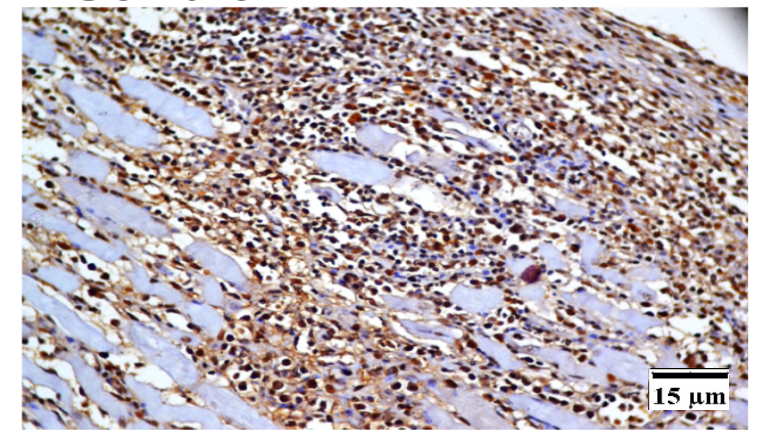

\section{Cis + bLF}

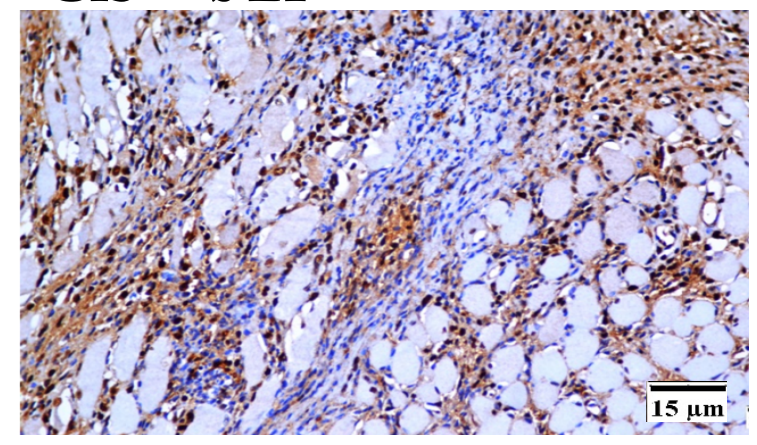

\section{Cis}

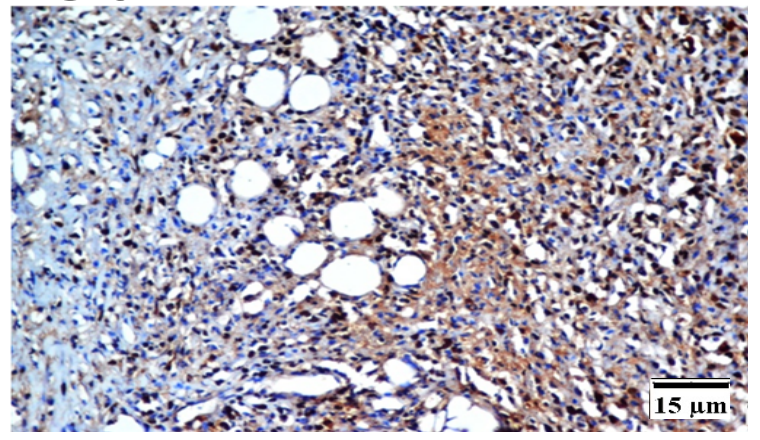

\section{Cis + MDP}

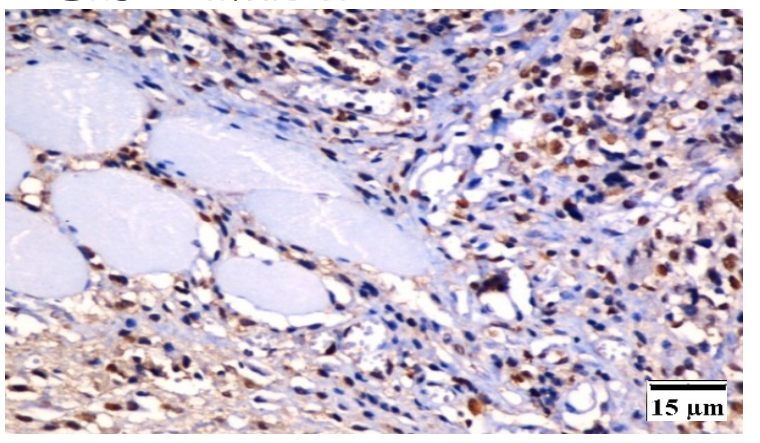

Figure 6. Representative light micrograph of the proliferation marker PCNA expression in tumor mass in EST-bearing mice of different groups" The brown stain referred to the positive reaction, the blue stain is hematoxylin counterstain $(\times 400)$.

\section{Control}

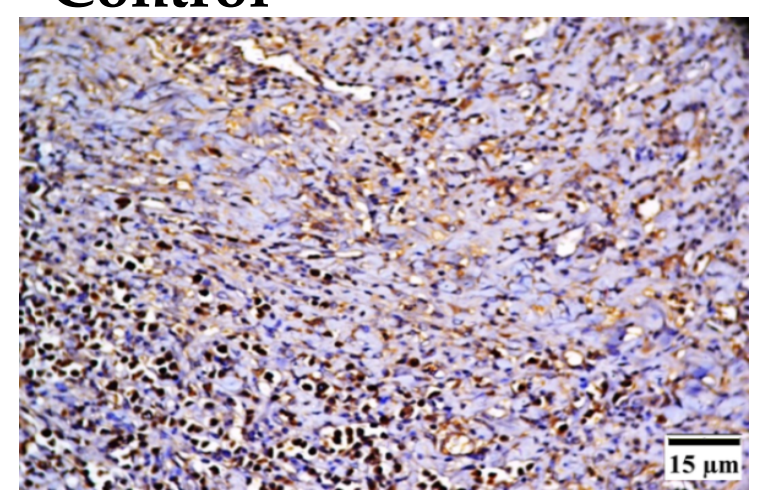

\section{Cis + bLF}

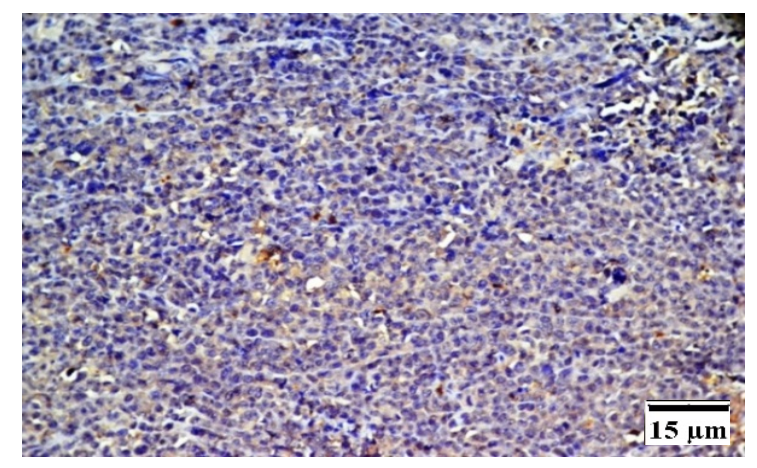

\section{Cis}

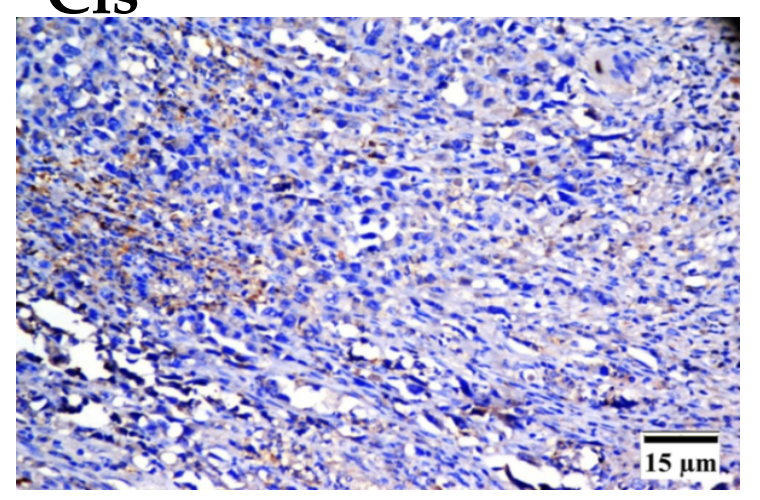

\section{Cis + MDP}

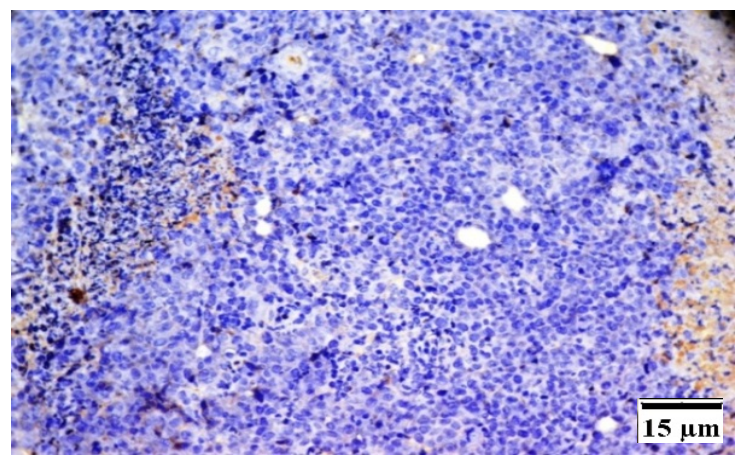

Figure 7. Representative light micrograph of the anti-apoptotic protein $\mathrm{Bcl}-2$ expression in tumor mass in EST-bearing mice of different groups" The brown stain referred to the positive reaction, the blue stain is hematoxylin counterstain $(\times 400)$. 


\section{Control}

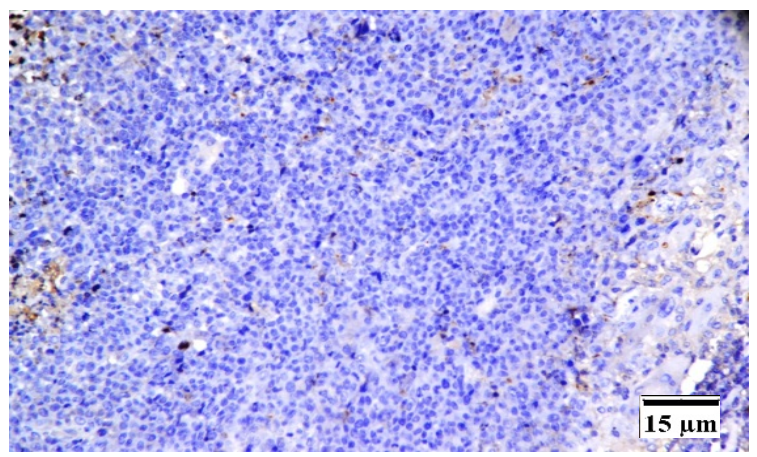

\section{Cis + bLF}

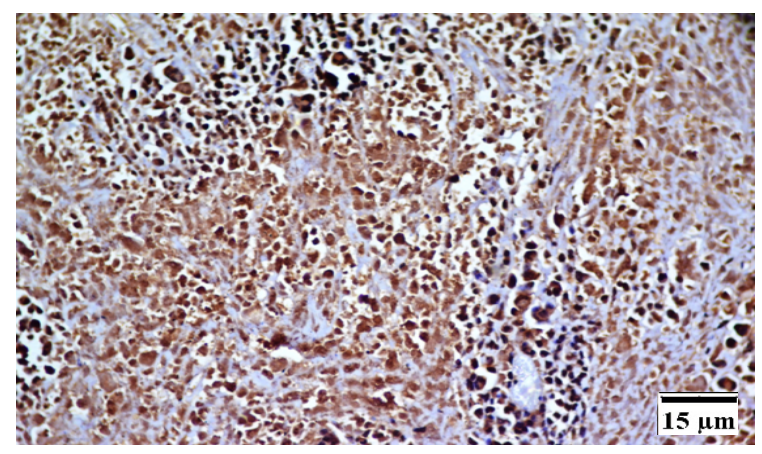

\section{Cis}

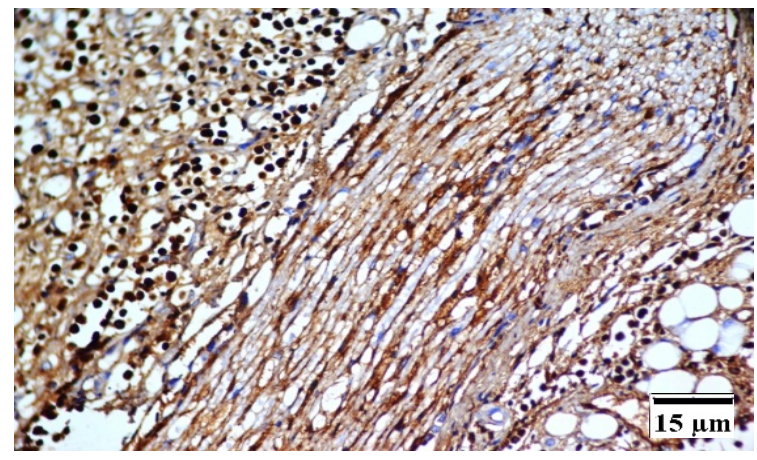

Cis + MDP

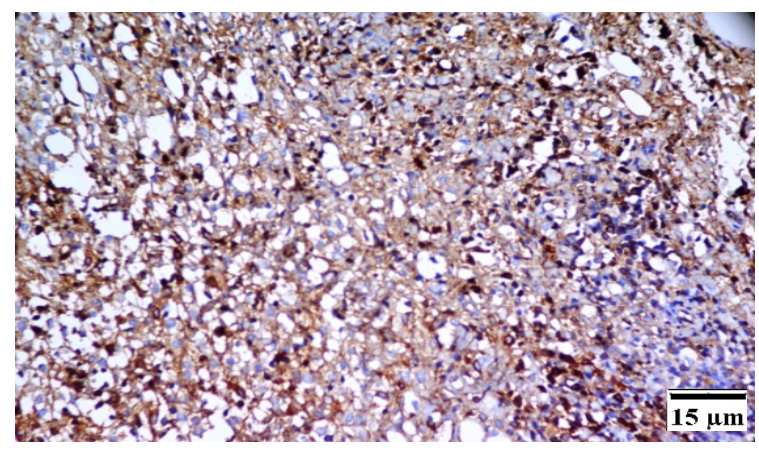

Figure 8. Representative light micrograph of the pro-apoptotic protein p53 expression in tumor cells in EST-bearing mice of different groups" The brown stain referred to the positive reaction, the blue stain is hematoxylin counterstain $(\times 400)$.

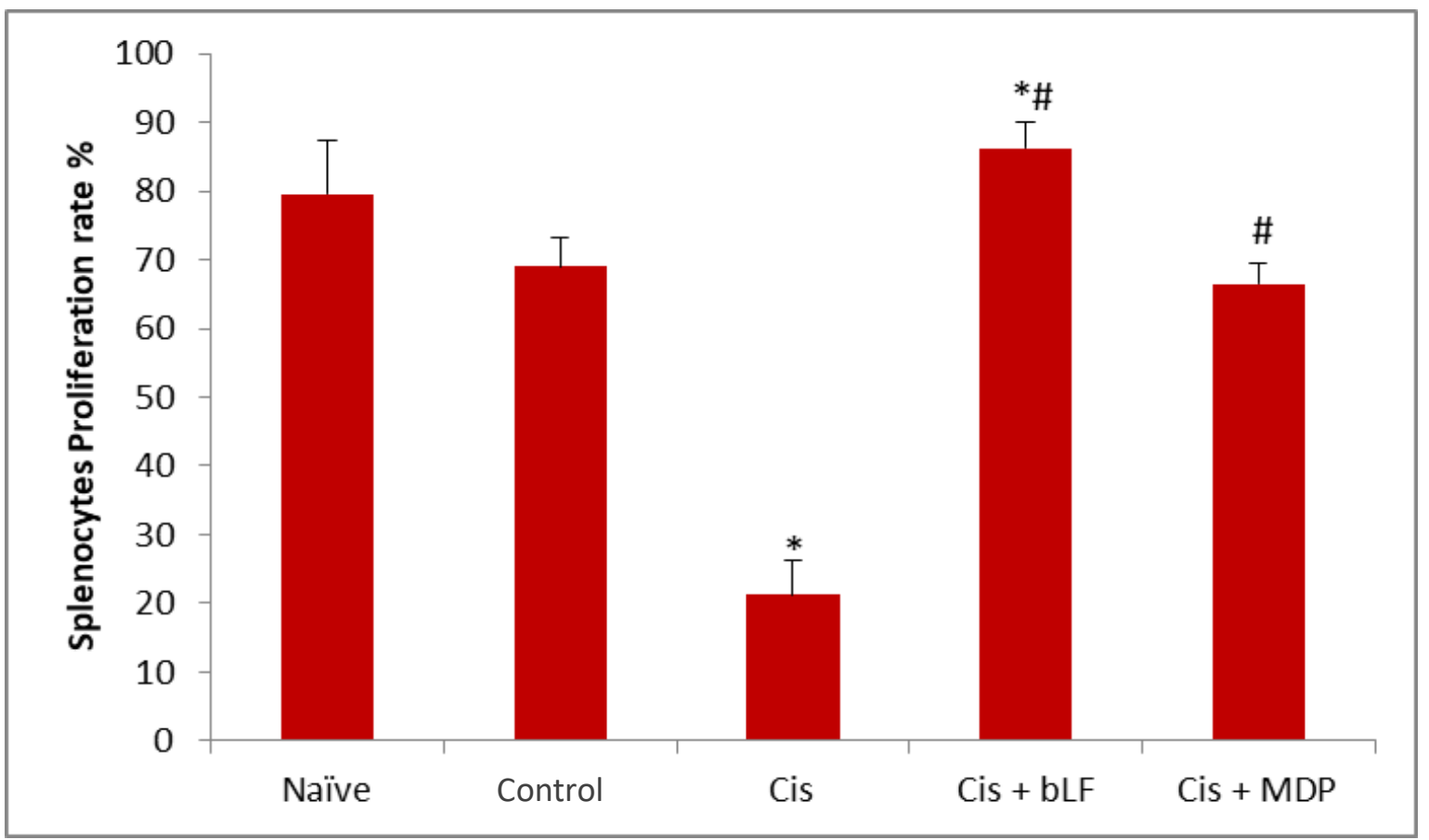

Figure 9. The effect of Cisplatin co-treatment with bLF or MDP on splenocytes proliferation rate" Data were expressed as the mean $\pm S D, n=5$. Statistical difference was calculated with an ANOVA and follow-up test (LSD). ${ }^{*} P<0.05$ indicated a significant difference compared to the control group. ${ }^{\#}<0.05$ indicated a significant difference compared to Cisplatin- treated mice. 
and those mono-treated with cisplatin, while an induced significant decrease in the hematocrit value compared to control mice. On the other hand, cisplatin co-treatment with MDP significantly $(P<0.05)$ increased RBCs, WBCs, platelets count, relative lymphocytes, hemoglobin concentration compared to cisplatin-treated mice, while caused a significant decrease $(P<0.05)$ in the relative granulocytes compared to cisplatin-treated animals. Fortunately, cisplatin co-treatment with bLF or MDP partially succeeded to restore many hematological values compared to cisplatin mono-treatment.

\section{DISCUSSION}

The current study showed that co-treatments of cisplatin with bLF or MDP can be potent antitumor agents. These results are in the same line with Li et al. (2017) LF can inhibit the growth of colon cancer cell line (HT29) in nude mice when administered alone in dose $(200 \mathrm{mg} / \mathrm{kg})$ or combination with the chemotherapeutic agent 5-FU. Consistently, Sun et al. (2012) demonstrated that oral administration of iron saturated -LF augmented tamoxifen therapy to delay the appearance of palpable tumors in breasts of female Balb/c mice, besides inhibiting their subsequent growth. Consistently, Varadhachary et al. (2004) found that oral rhLF inhibited the growth of squamous cell carcinoma (012) tumors in T-cell immunocompromised nu/nu mice. Previous report used oral rhLF alone and in combination with cisplatin to treat HNSCCA in a syngeneic murine model and the authors found that mono-treatment with rhLF or Cisplatin caused $61 \%$ or $66 \%$ tumor growth inhibition over placebo respectively, while co-administration showed $79 \%$ tumor growth inhibition.

MDP has been shown to successfully reduce tumor size when co-administered with cisplatin. These results are consistent with $\mathrm{Ma}$ et al., (2011) who demonstrated that MDP conjugate with paclitaxel (MTC-220) was efficacious in inhibiting tumor growth in xenograft models using human ovarian (A2780, ES-2), breast (MDA-MB-231, MCF-7), and lung (H460, A549, H1975) tumor cell lines. Furthermore, MDP derivatives have been shown to have tumoricidal activity via up-regulating the expression and production of macrophage cytokines as IL-1 $\alpha$, IL-1 $\beta$, IL- 6, IL- 8 and tumor necrosis factor $\alpha$ (Worth et al., 1999).

In this study, cisplatin-induced hepatotoxic and nephrotoxic effects represented in elevated levels of serum ALT, AST, urea, and creatinine besides histopathological alterations in liver, as the appearance of many abnormal bi-nucleated cells and marked cytoplasmic vacuolization of hepatocytes, besides histolpathological aspects in the kidney as the occurrence of edema, enlarged fragmented glomeruli and renal tubule damage with cytoplasmic vacuolization. These results are inconsistent with Ma et al. (2015) and Osman et al. (2015) who reported that cisplatin induced renal toxicity by elevated blood urea nitrogen and serum creatinine levels compared to their levels in normal mice, also caused histopathological changes such as tubular necrosis, desquamation in the renal cortex, tubular congestion and swelling, loss of brush border, appearance of pyknotic nuclei and congestion of renal blood vessels. Moreover, previous studies recorded that cisplatin leads to pathological changes in the liver presented as hepatocytes necrosis, central vein congestion, bile duct proliferation, cytoplasmic vacuolization accompanied by disturbances in liver functions presented as elevation in serum levels of ALT and AST (Park et al., 2009; Gong et al., 2015; Niu et al., 2017). The obtained data showed that co-treatment of cisplatin with bLF or MDP succeeded to partially modulate serum levels of ALT, AST, urea, and creatinine, also induced partial improvement in the histological structure of both liver and kidney.

In accordance with the current results, previous studies recorded that LF improved liver functions and histological structure, reduced oxidative stress, and fibrosis in rats with liver fibrosis (Hessin et al., 2015). Moreover, the ameliorative effect of LF against nephrotoxicity induced by cisplatin was previously reported by Kimoto et al. (2013) and Hegazy et al. (2016), through modulating the levels of urea and creatinine, reducing renal tubule damage. The hepatoprotective effect of MDP was previously reported by Cursio et al. (1998) as they recorded that MDP treatment improved liver status after normothermic liver ischemia in rats by reducing 
liver injury, retrieving serum levels of ALT and AST.

The current results proved muscular destructions in the skeletal muscles of the right thigh due to intramuscular injection with EACs. These pathological alterations may be owed to the pro-inflammmatory conditions induced by EACs which may, in turn, lead to a catabolic state causing such pathological alterations (DerTorossian et al., 2013). These observations were in harmony with Areida et al., (2015) who observed that muscle fibers of thigh muscle of Ehrlich solid tumor-bearing mice were invaded by deeply stained tumor cells, with a large area of necrosis. Consistently, Aldubayan et al. (2019) reported that Ehrlich tumor cells under the light microscope were manifest as sheets of small, highly chromatophilic tumor cells with inconsistent morphology.

Deregulated proliferation and inhibition of apoptosis lie at the heart of all tumor development and they present obvious targets for therapeutic interventions in all cancers (Evan and Vosden, 2001). In the present study, tumor cells in control mice exhibited a high proliferation rate represented in elevated expression of PCNA and the anti-apoptotic protein $\mathrm{BCl}-2$ while very weak expression of the pro-apoptotic protein p53. In accordance, previous studies recorded that Ehrlich tumor cells exhibited a high proliferation rate and low apoptosis percentage (Ahmed and Ahmed, 2015; Aldubayan et al., 2019; Ghoneum et al., 2019).

Interestingly, the presented results showed that cisplatin co-treatment with bLF or MDP was more effective than cisplatin mono-treatment on tumor cell proliferation and apoptosis. As shown, cisplatin co-treatment with bLF or MDP significantly decreased proliferation rate while induced apoptosis by inhibiting anti-apoptotic $\mathrm{BCl}-2$ expression and increasing the expression of pro-apoptotic p53. In harmony with the current results, Guedes et al. (2018) reported that bLF inhibited proliferation, induced apoptosis in vitro of prostate cancer Pc-3 and osteosarcoma Mg-63 cells. Consistently, bLF has been reported by Duarte et al., (2011) to induce apoptosis and inhibit proliferation in T47D and HS578D human breast cancer cell lines.
Similarly, Xu et al., (2010) also reported that bLF induced apoptosis by reducing the levels of intrinsic protein $\mathrm{Bcl}-2$ in stomach cancer cells. Furthermore, Gibbons et al., (2015) recorded that bLF both apo- or Fe- bLF markedly suppressed proliferation and inducing apoptosis in MDA-MB-231 and MCF-7 human breast cancer cell lines.

Moreover, MDP markedly suppressed tumor cell proliferation, whilst initiated tumor cell apoptosis by reducing levels of anti-apoptotic Bcl-2 and increasing the pro-apoptotic p53 expression. The observed anti-proliferative and apoptotic effects of MDP came following Yoon et al. (2016) who recorded that MDP can inhibit proliferation and induce apoptosis of oral squamous cell carcinoma by nucleotide oligomerization domain (NOD)-2 stimulation. Upon binding of NOD2 with its ligand, undergoes conformational changes, and various pathways could lead to nuclear factor-kappa B (NF-KB) activation which resulted in apoptosis and autophagy (Inohara et al., 2000; Yamaguchi et al., 2017). On another side, MDP is a peptidoglycan constituent of both grampositive and gram-negative bacteria, it is composed of $\mathrm{N}$-acetylmuramic acid (glycan moiety) linked by its lactic acid moiety to the dipeptide L-alanine-D-isoglutamin (Ellouz et al., 1974). The N-acetylmuramic (MurNAC) acid is a monosaccharide derivative of $\mathrm{N}$-acetyl glucosamine (GlcNAC) (Bhagavan, 2002). Nacetyl muramic acid is probable to exert the apoptotic effect in the current examined tumor model. Liang et al. (2018) recorded that GIcNAC improved the effect of TNF-related apoptosisinducing ligand (TRAIL)-induced apoptosis by activating death receptor (DR)-5 accumulations and clustering, which in turn recruited the apoptosis-initiating protease caspase-8 to form death-inducing signaling complex (DISC) and initiated apoptosis in human non-small cell lung cancer cells.

Tumors often establish an almost symbiotic relationship with their hosts by suppressing excessive inflammation and antitumor immune response (Goldszmid et al., 2014). In the present study, EST significantly decreased the percentage of the effector T-lymphocytes $\left(\mathrm{CD}^{+}{ }^{+} \mathrm{CD} 4^{+}\right.$and $\left.\mathrm{CD}^{+}{ }^{+} \mathrm{CD} 8^{+}\right)$, while significantly increased the expression of CD69 antigen "a 
negative regulator of the anti-tumor immune response" on T-lymphocytes $\left(\mathrm{CD}^{+} \mathrm{CD}^{+} \mathrm{CD} 69^{+}\right.$ and $\mathrm{CD}^{+} \mathrm{CD}^{+} \mathrm{CD}^{+} 9^{+}$) besides increasing the percentage of $\mathrm{CD} 11 \mathrm{~b}^{+} \mathrm{Ly} 6 \mathrm{G}^{+}$myloid derived suppressor cells (MDSCs). These data are consistent with Murdoch et al., (2008) who reported that tumor-bearing mice have a markedly elevated number of MDSCs $\left(\mathrm{CD} 11 \mathrm{~b}^{+} \mathrm{Gr} 1^{+}\right)$in their peripheral blood, bone marrow, and spleen compared with nontumorized mice. Moreover, the present results agree with Wen et al., (2018) who reported that large numbers of MDSCs accumulated in the tumor-bearing mice to be $\sim 7$-folds that of normal mice. Herein, the administered dose of the chemotherapeutic agent cisplatin " $2 \mathrm{mg} / \mathrm{kg}$, body weight" randomly decreased the percentages of the investigated effector immune cells $\mathrm{CD}^{+} \mathrm{CD}^{+}, \mathrm{CD}^{+} \mathrm{CD}^{+} \mathrm{CD} 69^{+}$, $\mathrm{CD}^{+}{ }^{\mathrm{CD}} 8^{+} \mathrm{CD}^{2} 9^{+}$, and $\mathrm{CD} 11 \mathrm{~b}^{+} \mathrm{Ly}_{6 \mathrm{G}^{+}}$.

The presented results are consistent with Shruthi et al. (2018) who reported the immunosuppressive action of cisplatin. On the other hand, co-treatments of cisplatin with bLF or MDP relieved the immunosuppressive impact of the administered dose of cisplatin through retrieving the percentages of $\mathrm{CD}^{+} \mathrm{CD}^{+}$, $\mathrm{CD}^{+}{ }^{+} \mathrm{CD} 8^{+}, \mathrm{CD}^{+} \mathrm{CD} 4{ }^{+} \mathrm{CD} 69^{+}, \mathrm{CD}^{+}{ }^{+} \mathrm{CD} 8^{+} \mathrm{CD} 69^{+}$, and $\mathrm{CD} 11 \mathrm{~b}^{+} \mathrm{Ly}_{6 \mathrm{G}}{ }^{+}$cells toward the normal values. These results are inconsistent with Artym et al. (2003a) who reported that oral administration of LF notably reconstitutes the splenocytes cellularity and enriches both $\mathrm{CD}^{+}$ and CD4+ cells in cyclophosphamideimmunosuppressed mice. In addition, a previous study demonstrated similar effects of LF on T lymphocytes by increasing expression of the CD4 marker in Jurkat $T$ cells (DhenninDuthille et al., 2000). Similarly, the immunomodulatory role of LF was reported by Tomita et al. (2009) who found that LF bound to receptors on enterocytes, dendritic cells, lymphocytes inducing the release of cytokines and increasing the number of $\mathrm{NK}, \mathrm{CD}^{+}$and $\mathrm{CD} 8^{+}$ cells.

In harmony with the current results, Heinzelmann et al. (2000) and Uehori et al. (2005) reported that antitumor efficacy of MDP and its derivatives may be via stimulating the immune response of mononuclear macrophage to release some cytokines and express more co- stimulatory molecules that are necessary for generation and differentiation of effector Tlymphocytes. Furthermore, a previous study revealed that MDP could induce dendritic cells maturity which in turn promoted the antitumor effects of T lymphocytes (Wang et al., 2011).

The health and immune status of the host is mostly relative to the immune organ indices (Zhao et al., 2009). In the present study, mice mono-treated with cisplatin showed a decrease in splenocytes proliferation, spleen, and thymus indices. On the other hand, mice co-treated with cisplatin and bLF or MDP restored splenocyte proliferation, spleen, and thymus indices compared to those treated with cisplatin. These results are in accordance with Shruthi et al., (2018) who recorded that both cisplatin and cyclophosphamide markedly decreased the thymus index in mice. Moreover, Artym et al. (2003b) reported that oral administration of LF could partially reconstitute the humoral immune response associated with elevation in $\mathrm{CD}^{+}$and $\mathrm{CD} 4^{+} \mathrm{T}$ lymphocytes and $\mathrm{B}$ cells and enhancement of spleen cells proliferation. Furthermore, the stimulatory effect of MDP on the proliferative capabilities of splenocytes was previously reported by Christiana et al. (2016). Likewise, Iribe and Koga (1984) reported that MDP significantly augmented the proliferative response of thymic T-lymphocytes to phytohaemagglutinin.

To estimate the ameliorative effect of certain therapy on the host, hematological and biochemical changes should be recorded during tumor therapies (Ganger and Koul, 2010). In the present study, mono-treatment with cisplatin leads to a sharp decrease in RBCs count, $\mathrm{Hb}$ concentration, hematocrit volume, PLT count, WBCs count, relative lymphocyte count, inducing anemia which may be attributed to its known myelosuppressive effects reported previously (Song et al., 2017), while causing an increase in relative granulocyte count which might be due to the acute inflammatory response. In accordance, Khynriam and Prasad (2001) proved that cisplatin induced hematoxic features as decreased RBCs count, $\mathrm{Hb}$ content, WBCs count, lymphopenia, neutropenia besides the development of erythrocyte morphological anomalies (microcytes, macrocytes, echinocytes and acanthocytes) in Dalton 
lymphoma bearing mice. On the other side, cotreatments of cisplatin with bLF or MDP mostly enhanced all hematological anomalies induced by cisplatin mono-treatment. These results are matched with Kanwar et al. (2008) who proved that bLF restored both peripheral RBCs and WBCs counts depleted by chemotherapy in preclinical studies, indicating the ability of bLF in treating anemia. Furthermore, Moastafa et al. (2014) reported that bLF could alleviate RBCs and WBCs counts, hemoglobin content in colorectal cancer patients who received bLF for three months.

Finally, in this study, Cisplatin mono- and cotreatments with bLF or MDP, fortunately, exhibited atrophy in the tumor mass accompanied by improvement in muscular strands with slight abnormalities.

\section{CONCLUSION}

Adjuvant therapy of bLF and MDP with cisplatin has potent anti-tumor properties. Co-treatment of bLF or MDP with cisplatin enhances the chemotherapy curative effects, regulate the proliferation and apoptosis of the tumor cells, modulate the immune response against the examined tumor, and to some extent ameliorate the adverse toxic effects of the cisplatin.

\section{CONFLICT OF INTEREST}

Authors declare that they have no conflicts of interest.

\section{FUDING}

There is no financial support for this study.

\section{REFERENCES}

Abdel Ghaffar F, Abd El latif $\mathrm{H}$, Gouida M, El-Elaimy I, Ibrahim $H$ (2019). Evaluation of the antitoxic effect of levamisole or taurine against high dose of cyclophosphamide in tumor-bearing mice. Archives of Oncology and Cancer Therapy. 2 (1):16-29.

Abdel Salam S, Salem M, Nassef M, Abdu S, El-Adl R (2017). Efficacy of combined administration of chemo-immunotherapy with bone marrow cells or granulocyte-colony stimulating factormobilized stem cells on expansion of myeloid and stem cells. Clin. Cancer Investig. J. 6(1): 7380.
Actor J, Hwang S, Kruzel M (2009). Lactoferrin as a natural immune modulator. Curr. Pharm. Des. 15(17): 1956-1973.

Ahmed O, Ahmed R (2015). Anti-proliferative and apoptotic efficacy of diallyl disulfide on Ehrlich ascites carcinoma. Hepatoma Research 1(2): 64-74. DOI: 10.4103/2394-5079.157602.

Aldubayan M, Elgharabwy R, Ahmed A, Tousson E (2019). Anti-neoplastic activity and curative role of avenanthramides against the growth of Ehrlich solid tumors in mice. Oxid. Med. Cell. Longev. https://doi.org/10.1155/2019/5162687.

Alekseeva L, Mironova N, Brenner E, Kurilshikov A, Patutina O, Zenkova M (2017). Alteration of the exDNA profile in blood seum of LLC-bearing mice under the decrease of tumour invasion potential by bovine pancreatic DNase I treatment. PLoS ONE, 12(2): e01711988. https://doi.org/10.1371/journal.pone.0171988

Areida S, Abd El-Azim A, Amer M (2015). Protective and Curative Effect of Thymoquinone on Ehrlich Solid Carcinoma Inoculated Mice. EJHM, 58: 129-142. DOI: 10.12816/EJHM.2015.15521.

Arriazu R, Pozuelo JM, Henriques-Gil N, Perucho T, Martín R, Rodríguez R, Santamaría L (2006). Immunohistochemical study of cell proliferation, $\mathrm{Bcl}-2$, p53, and caspase-3 expression on preneoplastic changes induced by cadmium and zinc chloride in the ventral rat prostate. J Histochem Cytochem. 54(9): 981-90. DOI:10.1369/jhc.5A6733.2006.

Artym J, Zimecki M, Kruzel M (2003a). Reconstitution of the cellular immune response by lactoferrin in cyclophosphamide-treated mice is correlated with renewal of T cell compartment. Immunobiol. 207: 197-205. https://doi.org/10.1078/0171-2985-00233.

Artym J, Zimecki M, Paprocka M, Kruzel M (2003b). Orally administered lactoferrin restores humoral immune response in immunocompromised mice. Immunology Letters 89:9$15 . \quad$ https://doi.org/10.1016/S01652478(03)00102-0.

Aston W, Hope D, Nowak A, Robinson B, Lake R, Lesterhuis W (2017). A systematic investigation of the maximum tolerated dose of cytotoxic chemotherapy with and without supportive care in mice. BMC Cancer 17:684. https://doi.org/10.1186/s12885-017-3677-7.

Baker E, Baker H (2005). Molecular structure, binding properities and dynamics of lactoferrin. Cell. Mol. Life Sci. 62: 2531-2539. https://doi.org/10.1007/s00018-005-5368-9.

Bhagavan N (2002). Heteropolysaccharides II: Proteoglycans and Peptidoglycans. In: Medical 
Biochemistry, 4th edition. Harcourt/Academic Press. Published by Elsevier Inc.

Bloksma, N., Hothuis, F., Willers, J. (1984). Muramyl dipeptide is a powerful potentiator of the antitumor action of various tumor necrotizing agents. Cancer Immunol Immunother. 17: 154159.

Christiana I, Aparnaa R, Rohit1, R, Nageswara Rao, D and Kaliraj P (2016). Effect of muramyl dipeptide and alum adjuvants on immunization with Filarial multi antigen peptide vaccine in mice model. Helminthologia, 53(3): $224-232$. https://doi.org/10.1515/helmin-2016-0022.

Cursio R, Gugenheim J, Panaia-Ferrari P, Lasfar A, Tovey M, Chastanet S, Saint-Paul M, Ferre' C, Mouiel J. (1998). Improvement of normothermic rat liver ischemia/reperfusion by muramyl dipeptide. J. Surg. Res., 80(2): 339344. https://doi.org/10.1006/jsre.1998.5445.

Dacie, S., Lewis, S. (1984). Practical Hematology. $6^{\text {th }}$ ed. UK: Chuechill Livingstone, 24-45.

Der-Torossian $H$, Wysong A, Shadfar S, Willis $M$, McDunn J, Couch M (2013). Metabolic derangements in the gastrocnemius and the effect of Compound A therapy in a murine model of cancer cachexia. J Cachexia Sarcopenia Muscle. 4(2):145-155. https://doi.org/10.1007/s13539-012-0101-7

Dhennin-Duthile I, Masson M, Damiens E, Fillebeen C, Spik G and Mazurier J (2000). Lactoferrin regulates the expression of $\mathrm{CD} 4$ antigen through the stimulation of the mitogenactivated protein kinase in the human lymphoblastic $\mathrm{T}$ Jurkat cell line. J. Cell. Biochem.79: 583-593.

Dkhil M, Al-Quraishy S, Aref A, Othman M, El-Deib K and Abdel Moneim A (2013). The potential role of Azadirachta indica treatment on cisplatinplatin-induced hepatotoxicity and oxidative stress in female rats. Oxid. Med. Cell. Longev. 2013:741817. https://doi.org/10.1155/2013/741817.

Duarte D, Nicolau A, Teixeira J, Rodrigues L (2011). The effect of bovine milk lactoferrin on human breast cancer cell lines. J Dairy Sci.94:6676. https://doi.org/10.3168/jds.2010-3629

Eastman, A. In Cisplatin: Chemistry and Biochemistry of a Leading Anticancer Drug; Lippert, B., Ed.; Verlag Helvetica Chimica Acta: Zurich; WileyVCH: Weinheim, Germany, 1999; pp 111-134.

Ellouz F, Adam A, Ciorbaru R, Lederer E (1974). Minimal structural requirements for adjuvant activity of bacterial peptidoglycan derivatives. Biochem. Biophys. Res. Commun. 59(4): 13171325. https://doi.org/10.1016/0006-
El-Sayyad H, Ismail M, Shalaby F, Abou-El-Magd R, Gaur R, Fernando A, Raj M, Ouhtit A (2009). Histopathological effects of cisplatinplatin, doxorubicin and 5-flurouracil (5-FU) on the liver of male albino rats. Int. J. Biol. Sci. 5(5):466-473. DOI:10.7150/ijbs.5.466

Evan G, Vosden K (2001). Proliferation, cell cycle and apoptosis in cancer. Nature, 411:342-348. https://doi.org/10.1038/35077213.

Florea A, Büsselberg D (2011). Cisplatin as an antitumor drug: Cellular mechanisms of activity, drug resistance and induced side effects. Cancers (Basel) 3(1): 1351-1371. https://doi.org/10.3390/cancers3011351

Gangar S, Sandhir R, Koul A (2010). Effects of Azadirachta indica on certain hematological parameters during benzo (a) pyrene induced murine fore stomach tumorigenesis. Eur. Rev. Med. Pharmacol. Sci. 14(12): 1055-1072.

Ghoneum M, Badr El-Din N, Mahmoud A, Tolentino L, Pan D, Hassan T (2019). Dietary baker's yeast sensitizes Ehrlich mammary adenocarcinoma to paclitaxel in mice bearing tumor. Oncol. Rep. 41:

3155-

3166. https://doi.org/10.3892/or.2019.7107

Gibbons J, Kanwar J, Kanwar R (2015). Iron-free and iron-saturated bovine lactoferrin inhibit survivin expression and differentially modulate apoptosis in breast cancer. BMC Cancer 15: 425. https://doi.org/10.1186/s12885-0151441-4.

Goldszmid R, Dzutsev A, Trinchieri G (2014). Host immune response to infection and cancer: unexpected commonalities. Cell Host Microbe 15(3):295-305. https://doi.org/10.1016/j.chom.2014.02.003

Gong C, Qian L, Yang H, Ji L, Wei H, Zhou W, Qi C, Wang C (2015). Hepatotoxicity and pharmacokinetics of cisplatinplatin in combination therapy with a traditional chinese medicine compound of Zengmian Yiliu granules in ICR mice and SKOV-3-bearing nude mice. BMC Complemen. Altern. Med. 15:283. https://doi.org/10.1186/s12906-015-0799-9

González-Chávez S, Arévalo-Gallegos S and RascónCruz Q (2009). Lactoferrin: structure, function and applications. Int. J. Antimicrob. Agents 33. http://doi.org/ 10.1016/j.ijantimicag.2008.07.020.

Goto T, Nishi T, Tamura T, Dev S, Takeshima H, Kochi M, Yoshizato K, Kuratsu J, Sakata T, Hofmann G, Ushio Y (2000). Highly efficient electro-gene therapy of solid tumor by using an expression plasmid for the herpes simplex virus thymidine kinase gene. Proc. Natl. Acad. Sci. USA. $\quad 97 \quad$ (1): 359. https://doi.org/10.1073/pnas.97.1.354. 
Guedes J, Pereira C, Rodrigues L, Côrte-Real M (2018). Bovine milk lactoferrin selectively kills highly metastatic prostate cancer Pc-3 and osteosarcoma Mg-63 cells In Vitro. Front. Oncol. $8: 200$ https://doi.org/10.3389/fonc.2018.00200.

Hegazy R, Salama A, Mansour D, Hassan A (2016). Reno protective effect of lactoferrin against chromium-induced acute kidney injury in rats: involvement of IL-18 and IGF-1inhibition. PLoS ONE 11(3): e0151486. https://doi.org/10.1371/journal.pone.0151486

Heinzelmann M, Polk J, H, Chernobelsky A, Stites T, Gordon E (2000). Endotoxin and muramyl dipeptide modulate surface receptor expression on human mononuclear cells. Immunopharmacol. 48: 117-128. https://doi.org/10.1016/S01623109(00)00195-8

Hessin A, Hegazy R, Hassan A, Yassin N, Kenawy S (2015). Lactoferrin enhanced apoptosis and protected against thioacetamide-induced liver fibrosis in rats. Maced. J. Med. Sci., 3(2):195201.

https://doi.org/10.3889/oamjms.2015.038

Ibrahim H, Abdul Ghaffar F, El-Elaimy I, Gouida M, Abd El latif $H$ (2018). Antitumor and immunemodulatory efficacy of dual-treatment based on levamisole and/or taurine in Ehrlich ascites carcinoma-bearing mice. Biomed. Pharmacother. 106, 43-49. https://doi.org/10.1016/j.biopha.2018.06.113

Ibrahim H, El-Elaimy I, Saad Eldein H, Badr B, Rabah D, Badr G (2013). Blocking type I interferone signaling rescues lymphocytes from oxidative stress, exhaustion, and apoptosis in a streptozotocin-induced mouse model of type I diapetes. Oxid. Med. Cell. Longev. https://doi.org/10.1155/2013/148725

Ibrahim H, Mohamed A, Salem M, Osman G, Morsi D (2020). Anti-neoplastic and immunomodulatory potency of co-treatment based on bovine lactoferrin and/or muramyl dipeptide in tumour-bearing mice. Toxicol. Res. 9(2):137-147

https://doi.org/10.1093/toxres/tfaa012

Ibrahim H, Mohammed-Geba K, Tawfic A, El-Magd M (2019). Camel milk exosomes modulate cyclophosphamide-induced oxidative stress and immuno-toxicity in rats. Food Funct. 10 (11):7523- 7532. DOI: 10.1039/C9FO01914F

Ibrahim H, Xuan X, Nishikawa Y (2010). Toxoplasma gondii cyclophilin 18 regulates the proliferation and migration of murine macrophages and spleen cells, Clin. Vaccine Immunol. 17 (9), 1322-1329. DOI: 10.1128/CVI.00128-10 ligo $\mathrm{M}$, Alexander $\mathrm{D}$, Long $\mathrm{N}, \mathrm{Xu} \mathrm{J}$, Fukamachi K, Futakuchi M, Takase M, Tsuda H (2009). Anticarcinogenesis pathways activated by bovine lactoferrin in the murine small intestine. Biochemie.

91:86-101. https://doi.org/10.1016/j.biochi.2008.06.012

Iribe H, Koga T (1984). Augmentation of the proliferative response of thymocytes to phytohemagglutinin by the muramyl dipeptide. Cell. Immunol. 88:9-15. https://doi.org/10.1016/0008-8749(84)900479

Inohara N, Ogura Y, Fontalba A, Gutierrez O, Pons F, Crespo J, Fukase K, Inamura S, Kusumoto $S$, Hashimoto M, Foster S, Moran A, FernandezLuna J, Nunez G (2003). Host recognition of bacterial muramyl dipeptide mediated through NOD2. Implications for Crohn's disease. J Biol Chem. 278(8):5509-5512. DOI:10.1074/jbc.C200673200

Karadeniz A, Simsek N, Karakus E, Yildirim S, Kara A, Can I, Kisa F, Emre H, Turkeli, M (2011). Royal jelly modulates oxidative stress and apoptosis in liver and kidneys of rats treated with cisplatinplatin. Oxid. Med. Cell. Longev. https://doi.org/10.1155/2011/981793.

Kanwar J, Palmano K, Sun X, Kanwar R, Gupta R, Haggarty N, Rowan A, Ram S, Krissansen G (2008). Iron-saturated' lactoferrin is a potent natural adjuvant for augmenting cancer chemotherapy. Immunol. Cell. Biol. 86(3): 277288. https://doi.org/10.1038/sj.icb.710 0163

Khynriam D, Prasad S (2001). Hematotoxicity and blood glutathione levels after cisplatinplatin treatment of tumor-bearing mice. Cell Biol. Toxicol. 17:357-370. https://doi.org/10.1023/A:1013784115683

Kimoto $Y$, Nishinohara $M$, Sugiyama A, Haruna A, Takeuchi T (2013). Protective effect of lactoferrin on cisplatinplatin-induced nephrotoxicity in rats. J. Vet. Med. Sci. 75(2): 159-164. https://doi.org/10.1292/jvms.120154

Legrand D, Pierce A, Elass E, Carpentier M, Mariller C, Mazurier J (2008). Lactoferrin Structure and Functions, in: Z. Bösze (Ed.), Bioactive Components of Milk, Springer New York, New York, NY, 163-194.

Li H, Li, M, Luo C, Wang J, Zheng N (2017). Lactoferrin exerts anti-tumor effects by inhibiting angiogenesis in a HT29 human colon tumor model. J. Agric. Food Chem. 65(48): 1046410472.

https://doi.org/10.1021/acs.jafc.7b03390.

Liang Y, Xu W, Liu S, Chi J, Zhang J, Sui A, Wang L, Liang Z, Li D, Chen Y, Niu H (2018). N- 
acetylglucosamine sensitizes non-small cell lung cancer cells to TRAIL-induced apoptosis by activating death receptor 5. Cell. Physiol. Biochem. 2054-2070. https://doi.org/10.1159/000488042.

Ma P, Zhang S, Su X, Qui G, Wu Z (2015). Protective effects of icariin on cisplatinplatin-induced acute renal injury in mice. Am. J. Transl. Res. 7(10): 2105-2114.

Ma Y, Zhao N, Liu G (2011). Conjugate (MTC-220) of muramyl dipeptide analogue and paclitaxel prevents both tumor growth and metastasis in mice. J. Med. Chem. 54: 2767-2777. https://doi.org/10.1021/jm101577z.

Mir M, Arab M, Shahraki M, Mashhadi M, Salar M, Aval F, Karimfar M (2015). Toxic effects of cisplatinplatin on hepatocytes and liver enzymes of rats. ASJ 12(4): 171-176.

Moastafa T, El-Sissy A, El-Saeed G, Koura M (2014). Study on the therapeutic benefit on lactoferrin in patients with colorectal cancer receiving chemotherapy.

https://doi.org/10.1155/2014/184278.

Morsi D, Ibrahim H, Mohamed A, Osman G, Salem M (2020). Lactoferrin as an immunomodulatory and iron binding agent: Possible clinical implication in COVID-19. Inter. J. Cancer Biomed. Res. DOI: 10.21608/JCBR.2020.31253.1041

Murdoch C, Muthana M, Coffelt S, Lewis C (2008). The role of myeloid cells in the promotion of tumor angiogenesis. Nat. Rev. Cancer. 8:618631. https://doi.org/10.1038/nrc2444.

Mukherjee P, Nema N, Bhadra S, Mukherjee D, Braga F, Matsabisa M (2014). Immunomodulatory leads from medicinal plants. Indian J Tradit Knowledge 13:235-256.

Noaman E, Badr El-Din N, Bibars M, Abou Mossallam A, Ghoneum M (2008). Antioxidant potential by ara-binoxylan rice bran, MGN-3/biobran, represents a mechanism for its oncostatic effect against murine solid Ehrlich carcinoma. Cancer Lett. 268 (2): 348-359. https://doi.org/10.1016/j.canlet.2008.04.012.

Niu C, Ma M, Han X, Wang Z, Li H (2017). Hyperin protects against cisplatinplatin-induced liver injury in mice. Acta Cir. Bras. 32(8):633-640. https://doi.org/10.1590/s0102865020170080000005

Osman A, Alqahtani A, Damanhouri Z, Al-Harthy S, ElShal M, Ramadan W, Kamel F, Osman M, Khan M (2015). Dimethylsulfoide exacerbates cisplatinplatin-induced cytotoxicity in Ehrlich ascites carcinoma cells. Cancer Cell Int 15:104. https://doi.org/10.1186/s12935-015-0258-1.

Parhi P, Mohanti C, Sahoo S (2012). Nanotechnologybased combinational drug delivery: An emerging approach for cancer therapy. Drug Discov. Today 17-18, 10441052.https://doi.org/10.1016/j.drudis.2012.05 .010 .

Park H, Ju E, Jo S, Jung U, Kim S, Yee S (2009). Enhanced antitumor efficacy of cisplatinplatin in combination with HemoHIM in tumorbearing mice. BMC Cancer 9:85. https://doi.org/10.1186/1471-2407-9-85.

Puddu P, Valenti P, Gessani S (2009). Immunomodulatory effects of lactoferrin on antigen presenting cells. Biochemie 91:11-18. https://doi.org/10.1016/j.biochi.2008.05.005

Salem M, El Kholy S, Al-Atrash A, Samy D (2016). Tumor burden and cisplatinplatin treatment alters the expression levels of microRNA-146a and -155 in spleen and cancer cells in an experimental mouse model of Ehrlich ascites carcinoma. J. Solid Tumors 6(1): 78-86.

Shruthi S, Vijayalaxmi K, Shenoy B (2018). Immunomodulatory effects of gallic acid against cyclophosphamide- and cisplatinplatininduced immunosuppression in Swiss Albino mice. Indian J. Pharm. Sci. 80 (1):150-160. DOI:10.4172/pharmaceuticalsciences. 1000340.

Song Z, Chang H, Han N, Liu Z, Liu Y, Wang H, Shao J, Wang Z, Gaoa H, Yin J (2017). He-Wei granules (HWKL) combat cisplatinplatin-induced nephrotoxicity and myelosuppression in rats by inhibiting oxidative stress, inflammatory cytokines and apoptosis. RSC Adv. 7:1979419807. https://doi.org/10.1039/C7RA02830J.

Souvannavong V, Brown S, Adam A (1990). Muramyl dipeptide (MDP) synergizes with interleukin 2 and interleukin 4 to stimulate, respectively, the differentiation and proliferation of B cells. Cell Immunol. 126: 106-116. https://doi.org/10.1016/0008-8749(90)90304A

Sun X, Jiang R, Przepiorski A, Reddy S, Palmano K, Krissansen G (2012). Iron-saturated" bovine lactoferrin improves the chemotherapeutic effects of tamoxifen in the treatment of basallike breast cancer in mice. BMC Cancer 12:591. https://doi.org/10.1186/1471-2407-12-591.

Suvarna K, Layton C, Bancroft J (2018). Bancroft's Theory and Practice of Histological Techniques, 8th Edition, London, Elsevier; 672.

Thundimadathil J (2012). Cancer treatment using peptides: current therapies and future prospects. J. Amino Acids 112. https://doi.org/10.1155/2012/967347

Tomita M, Wakabayashi H, Shin K, Yamaushi K, Yaeshima T, Iwatsuki K (2009). Twenty-five years of research on bovine lactoferrin 
applications. Biochemie 91(1): 52-57. https://doi.org/10.1016/j.biochi.2008.05.021.

Uehori J, Fukase K, AkazawabT, Uematsu S, Akira S, Funami K, Shingai M, Matsumoto M, Azuma I, Toyoshima K, Kusumoto S, Tsukasa Seya T (2005). Dendritic cell maturation induced by muramyl dipeptide (MDP) derivatives: monoacylated MDP confers TLR2/TLR4 activation. J. Immunol. 174 (11):7096-7103. https://doi.org/10.4049/jimmunol.174.11.709 6

Varadhachary A, Wolf J, Petrak K, O'malley Jr, B, Spadaro M, Curcio C, Forni G, Pericle F (2004). Oral lactoferrin inhibits growth of established tumors and potentiates conventional chemotherapy. Int. J. Cancer 111 (3): 398-403.

https://doi.org/10.1002/ijc.20271

Vollmer W, Blanot D, de Pedro M (2008). Peptidoglycan structure and architecture. FEMS Microbial. Rev. 32 (2): 149-167. https://doi.org/10.1111/j.15746976.2007.00094.x

Wang L, Li Z, Pang X, Sun L (2011). Muramyl Dipeptide modulates differentiation, maturity of dendritic cells and anti-tumor effect of DCmediated $T$ cell in acute leukemia children. Human Vaccines 7(6): 618-624. https://doi.org/10.4161/hv.7.6.14988.

Wen X, Zheng P, Ma Y, Ou Y, Huang W, Li S, Liu S, Zhang $X$, Wang $Z$, Zhang $Q$, Cheng $W$, Lin R, Li $H$, Cai Y, Hu C, Wu N, Wan L, Pan T, Rao J, Bei X, Wu W, Jin J, Yan J, Liu G (2018). Salutaxel a conjugate of docetaxel and a muramyl dipeptide (MDP) analogue, Acts as multifunctional prodrug that inhibits tumor growth and metastasis. J. Med. Chem. 61 (4): 1519-1540.

https://doi.org/10.1021/acs.jmedchem.7b014 07.
Worth L, Jia S, An T, Kleinerman E (1999). ImmTher, a lipophilic disaccharide derivative of muramyl dipeptide, up-regulates specific monocyte cytokine genes and activates monocytemediated tumoricidal activity. Cancer Immunol Immunother, 48: 312-320. https://doi.org/10.1007/s002620050580.

Xu X, Jiang H, Li H, Zhang T, Zhou Q, Liu N (2010). Apoptosis of stomach cancer cell SGC-7901 and regulation of Akt signaling way induced by bovine lactoferrin. J. Dairy. Sci., 93: 23442350. https://doi.org/10.3168/jds.2009-2926.

Yamaguchi N, Suzuki $Y$, Mahbub M, Takahashi $H$, Hase R, Ishimaru $Y$, Sunagawa $H$, Watanabe $R$, Eishi Y, Tanabe T (2017). The different roles of innate immune receptors in inflammation and carcinogenesis between races. Environ Health Prev Med. 22(1): 70. https://doi.org/10.1186/s12199-017-0678-8.

Yamauchi K, Wakabayachi H, Shin K, Takase M (2006). Bovine lactoferrin: benefits and mechanism of action against infections. Biochem. Cell. Biol. 84(3): 291296. https://doi.org/10.1139/o06-054.

Yoon H, Ahn M, Kwon S, Kim D, Lee J, Yoon J (2016). Nucleotide-binding oligomerization domain 2 (NOD2) activation induces apoptosis of human oral squamous cell carcinoma cells. J. Oral. Pathol. Med. 45(4): 262-7. https://doi.org/10.1111/jop.12354.

Zhao N, Wang L, Mou H, Liang M, Yue W (2009). Synergism and attenuation effects of taurine on cyclophosphamide. Chin J Cancer 28(3): 204208. 


\section{Egyptian Association for Cancer Research (EACR)}

http://eacr.tanta.edu.eg/

EACR is an NGO society that was declared by the Ministry of Social Solidarity (Egypt) No. 1938 in 19/11/2014 based on the initiative of Prof. Mohamed Labib Salem, the current Chairman of EACR. EACR aims primarily to assist researchers, in particular young researchers in the field of cancer research through workshops, seminars and conferences. Its first international annual conference entitled "Anti-Cancer Drug Discovery" was successfully organized in April 2019 (http://acdd.tanta.edu.eg). Additionally, EACR aims to raise the awareness of the society about the importance of scientific research in the field of cancer research in prediction, early diagnosis and treatment of cancer. EACR is also keen to outreach the scientific community with periodicals and news on cancer research including peer-reviewed scientific journals for the publication of cutting-edge research. The official scientific journal of EACR is "International Journal of Cancer and biomedical Research (IJCBR: https://jcbr.journals.ekb.eg) was successfully issued in 2017 and has been sponsored by the Egyptian Knowledge Bank (EKB: www.ekb.eg).

\section{EACR Chairman,}

Prof. Mohamed Labib Salem, PhD

Professor of Immunology

Faculty of Science, Tanta Universiy, Egypt 
International Journal of Cancer and Biomedical Research (IJCBR), a publication of the Egyptian Association for Cancer Research (EACR), is a peer-reviewed online journal published quarterly. The journal allows free access (Open Access) to its contents and permits authors to self-archive a final accepted version of the articles on any OAl-compliant institutional / subject-based repository.

\section{Aim And Scope}

Aim: The main aim of IJCBR is to attract the best research in animal and human biology in health and diseases from across the spectrum of the biomedical sciences at the molecular, cellular, organ, and whole animal levels especially those that are related to cancer research, including causes, prediction, diagnosis, prognosis and therapy.

Scope: It is essential reading for all researchers interested in biochemistry, cancer, microbiology, nutrition, physiology, genetics, immunology, epidemiology, medical economics, human biology, bioinformatics, biotechnology, nanotechnology, and disease modeling.

\section{Publication Ethics}

Researchers should conduct their research from research proposal to publication in line with the best practices and codes of conduct of relevant professional bodies and/or national and international regulatory bodies. IJCBR accepts manuscripts prepared in accordance with the "Uniform Requirements for Submission of Manuscripts for Biomedical Journals adopted by the International Committee of Medical Journal Editors (ICMJE) and the Committee on Publication Ethics (COPE). Details of ICMJE and COPE are available at http://www.icmje.org/ and http://publicationethics.org/

\section{Peer Review Process}

After the IJCBR editor receives a manuscript, the first step is to confirm that the manuscript meets the journal's rules for content and format, including similarity check (plagiarism) which should be less than $25 \%$. If the manuscript meets the journal's rules, the editor then assign it to the double-blind peer review process. The IJCBR editor send the manuscript to at least two experts in the field for RIGOROUS scientific evaluation. The experts called peer reviewers - will then prepare a report that assesses the manuscript and return it to the editor through the IJCBR portal. Upon the first submission, this reviewing process takes about 4 to 6 weeks. After reading the peer reviewer's report, the editor will decide one of the following four options:

1. Reject the manuscript.

2. Accept the manuscript

3. Ask the authors to revise and resubmit the manuscript after responding to the peer reviewers' feedback.

4. Ask for peer-review from additional reviewers.

If the authors resubmit the manuscript, the IJCBR editor will ask the same peer-reviewers to look over the manuscript again to confirm that their concerns have been addressed. This is called re-review process. This second revision (if applicable) takes about another 4 to 6 weeks. At this point, the abstract of the article appears in press. The online publication (the PDF format) of the final version of the manuscript takes from 2 to 4 weeks. As such, the total publication cycle takes from 2 to 4 months. This cycle can be reduced to 4 to 6 weeks (fast track publication) for the manuscripts with outstanding findings.

The peer-review process used by IJCBR includes comments on errors in the study's methods or analysis that raise questions about the findings, or sections that need clearer explanations. The peer-review process also includes the importance and novelty of the manuscript and its interest to the journal's audience. The IJCBR uses double-blind review, which means that both the reviewers and authors identities are concealed from the reviewers, and vice versa, throughout the review process. To facilitate this, authors need to submit a Title Page containing the Authors details and Blinded Manuscript with no author details as 2 separate files. 


\section{Publisher}

The International Journal of Cancer and Biomedical Research (IJCBR) is an International and interdisciplinary journal of preclinical and clinical studies in the area of cancer and biomedical research. It is a peer-reviewed journal in English, published quarterly (in March, June, September, and December) by the Egyptian Association for Cancer Research (EACR) in both print and online formats (4 issues making a volume). Special issues or supplements may also be produced from time to time upon agreement with the Editorial Board.

\section{Scope}

The main aim of IJCBR is to attract the best research in animal and human biology in health and diseases from across the spectrum of the biomedical sciences at the molecular, cellular, organ, and whole animal levels especially those that are related to cancer research, including causes, prediction, diagnosis, prognosis and therapy.

\section{Publication Fees}

The journal does charge for submission, processing or publication of manuscripts (2000 LE for Egyptians or $\$ 300$ for non-Egyptians; EACR members receive 15\% discount on publication). Of them Peer-review fees (300 LE) should be paid on submission (non-refundable). For the fast track production of the accepted manuscript, another $500 \mathrm{LE}$ is paid.

General specifications for different types of article

- Submitted manuscripts should not have been published previously, except in a limited form (e.g. short communication to a symposium or as part of MSc or PhD theses) and should not be under consideration for publication by other journals.

- All co-authors should agree with the content of the manuscript. Authors must have obtained permission to use any copyrighted material in the manuscript before submission.

\section{IJCBR publishes different types of articles}

- Original Article (6000 words with $\mathbf{4}$ tables and $\mathbf{4}$ figures, maximum $\mathbf{8}$ display items): Articles with novel findings are the target of IJCBR. Articles presenting a detailed description of a new technique, comparison of existing methods, meta-analyses with comprehensive and in-depth discussion are considered. Papers in a numbered series are not accepted unless all are submitted at the same time.

- Short communications or case study (3000 words with 4 display items): Short communications present exceptionally exciting, novel or timely contents are considered. They will be peer-reviewed in the same way as research papers. The references are restricted to 15 .

- Reviews or systematic review (9000 words with $\mathbf{1 0}$ display items): They are invited by the Editorial Board or unsolicited. Review articles have to be contemporary and comprehensive and add information to the knowledge. Sharp critical analyses of novel data or concepts are encouraged. When relevant, a statistical analysis of data and a meta-analysis approach are recommended.

- Opinion papers, letter to the editor or comment to the editor (1500 words with $\mathbf{2}$ display items): They are submitted by invitation of the Editorial Board. They are short papers, which aim to inform scientists, industry, and the public and policymakers about cutting-edge issues in research or the impact of research. They reflect the opinion of their authors who bear full responsibility of the published paper. The references are restricted to 10 .

- Conference/Symposium papers: The journal will consider for publication the results of original work and critical reviews that are presented at conferences/symposia. Symposium organizers who wish to publish bundles of papers from a symposium/conference in IJCBR should first contact the Editor-inChief of the IJCBR (EACR@unv.tanta.edu.eg) for agreement. Supplementary material can be proposed and will be made available online. The responsibility for the preparation of a paper in a form suitable for publication lies with the author.

- Thesis: IJCBR can publish the summary and abstract of Master and PhD theses in a special issue. 
English: Good quality of written English is required. Spelling may be in British or American English but must be consistent throughout the paper. Care should be exercised in the use of biological terminology that is ill-defined or of local familiarity only. We recommend that authors have their manuscripts checked by an English language native speaker before submission.

Manuscript layout: Manuscripts should be prepared using a standard word processing program and presented in a clear readable format with easily identified sections and headings. The manuscript layout is based on the following directions.

- The main text contains Title, Abstract, Keywords, Introduction, Material and Methods, Results, Discussion, References, Tables, figures.

- The title needs to be concise and informative. Use bold, with an initial capital for the first word only and for words that ordinarily take capitals

- Short (running) title (max 80 characters including spacing).

- The article text should be typed with double-line spacing with wide margins $(2.5 \mathrm{~cm})$.

- The lines must be continuously numbered; the pages must also be numbered.

- Font Calibri 12 should be used for the text, and 12 for the tables, figure legends and references.

- The sections should typically be assembled in the following order:

- Title page contains title, authors' names, full affiliations, acknowledgements and the corresponding author's contacts and Short title.

Abstract (max 250 words, single paragraph): The abstract should be complete and understandable without citation, references, table or figure. Use structured abstract: Background, Aim, Materials \& Methods, Results and Conclusion. The context and the rationale of the study are presented succinctly to support the objectives. The experimental methods and main results are summarized but should not be overburdened by numerical values or probability values. The abstract ends with a short and clear conclusion.

Keywords: Up to five short and specific keywords should complement the title with respect to indicating the subject of the paper in alphabetic order.

Introduction: The introduction briefly outlines the context of the work, presents the current issues that the authors are addressing and the rationale to support the objectives, and clearly defines the objectives.

Material and methods: Material and methods should be described in sufficient details so that others can repeat the experiment. Reference to previously published work may be used to give methodological details, provided that said publications are readily accessible and in English. The code of ethics should be followed for all experiments use animals or human samples.

Statistical analysis of results: The statistical design and the models of statistical analysis must be described, as well as each of the statistical methods used. Sufficient statistical details must be given to allow replication of the statistical analysis. The experimental unit should be defined (e.g. individual or group of animals).

Results: Data are presented as tables and figures. Brief description of the results for each table and figure should be presented. Unpublished data can be mentioned when necessary.

Discussion: Should be separate from the Results section and should focus only on intra- and inter-data discussion (the data in the results section) as well as with the relative data in the literature. Don't repeat information already presented in the Introduction section. Start the first paragraph in the Discussion with a paragraph stating the rationale behind the study, the objectives and the main findings. End Discussion with a short conclusion.

Acknowledgements: In this section, the authors may acknowledge (briefly) their support staff.

Conflict of interest: All papers with a potential conflict of interest must include a description/explanation in a separate heading.

Funding details: The authors should state the source of findings of the study (with research funder and/or grant number). If no fund, the authors should state that the study is self-funded. 


\section{References}

Citation of references: In the text, references should be cited by the author(s) surname(s) and the year of publication (e.g. Salem, 2020). References with two authors should be cited with both surnames (e.g. Salem and Meshrif, 2021). References with three or more authors should be cited with the first author followed by et al. (in italics; e.g. Salem et al., 2021). Names of organizations used as authors (e.g. Food and Drug Administration) should be written out in full in the list of references and on the first mention in the text. Subsequent mentions may be abbreviated (e.g. FDA).

- List of references. Literature cited should be listed in alphabetical order by authors' names. It is the author's responsibility to ensure that all references are correct. All authors should be written and so the full journal name.

- References from journal articles are formatted in APA as this example: Al-Amoudi WM (2018). Toxic effects of Lambda-cyhalothrin on the rat thyroid. Involvement of oxidative stress and ameliorative effect of ginger extract. Toxicology Reports, 5: 728-736.

- References from books or official reports are formatted as this example. Kebreab E, Dijkstra ANM, Bannink A, Gerrits WJJ, \& France J (2006). Nutrient digestion and utilization in farm animals. CABI Publishing. Wallingford, UK.

- References from chapters or parts of books are formatted as this example. Nozière $P, \&$ Hoch $T$ (2006). Modelling fluxes of volatile fatty acids from rumen to portal blood. In: Nutrient digestion and utilization in farm animals (Kebreab E, Dijkstra ANM, Bannink A, Gerrits WJJ \& France J, eds.), pp. 40-47. CABI Publishing. Wallingford, UK.

Tables:

The data should be presented in tables or in graphs, not both.

- Each table should be placed on a separate page at the end of the main text.

- Tables are numbered consecutively using Arabic numbering. They are referred to as Table 1 , Table 2, etc., with capital ' $T$ ', no italics

- Each table has its explanatory caption. The caption is sufficient to permit the table to be understood without reference to the text.

- Abbreviations used in tables/figures have to be defined either as footnotes or in the caption.

Figures

- Package the figures in a single PowerPoint file. Each figure in a separate slide.

- Figure size should be readable in a width of approximately 8-175 $\mathrm{mm}$ (i.e. the maximum size of printing over two columns).

- Ensure that the font size is large enough to be readable at the final print size, use Calibri font to ensure that they are consistent throughout the figures.

- The figures should preferably be provided as TIFF or EPS files.

- The resolutions of figures must be at least $300 \mathrm{dpi}$.

- Preparation of images for a manuscript: For guidance, we refer to the Journal of Cell Biology's instructions to authors (http://jcb.rupress.org/site/misc/ifora.xhtml\#image_aquisition).

- If a cropped image is included in the main text of a paper (e.g. a few lanes of a gel), display the full original image, including the appropriate controls, the molecular size ladder and/or the scale as relevant, as a single figure in a Supplementary Material file to facilitate peer-review and for subsequent online publication.

- Supplementary material is submitted along with the main manuscript in a separate file and identified at uploading as "Supplementary File - for Online Publication Only" The title of the article is included at the top of the supplementary material.

Corresponding author's guidelines: Upon acceptance the corresponding author is required to send his/her recent formal photo to be attached to the front page of the article. 


\title{
International Journal of Cancer \& Biomedical Research
}

(IJCBR) Online ISSN 2682-2628

\author{
Editor-in-Chief \\ Mohamed Labib Salem, PhD \\ Tanta University, Egypt
}

\begin{tabular}{l} 
EACR Board \\
\hline Nehal Elmashad, MD \\
Tanta University, Egypt \\
Nabil Mohy Eldin, PhD \\
Kafrelsheikh University, Egypt \\
Doaa Al-Ghareeb, PhD \\
Alexandria University, Egypt \\
Abdel-Aziz Zidan, PhD \\
Damanhour University, Egypt
\end{tabular}

\begin{tabular}{l} 
Managing Editor \\
\hline Wesam Meshrif, PhD \\
Tanta University, Egypt \\
Sohaila Galal, PhD \\
Tanta University, Egypt \\
Production and Contact \\
\hline Hamdi Kandil \\
Tanta University, Egypt \\
Email: ljcbr100@gmail.com
\end{tabular}

\section{Advisory Board}

Alberto Montero, MD

Taussig Cancer Center, Cleveland,

USA

Yi Zhang, MD

Zhengzhou University, China

Mark Robunstein, Ph D

Medical University of South

Carolina, USA

Mohsen Farid, Ph D

Derby University, USA

Natarajan Muthusamy, Ph D

Ohio State University, USA

Hideki Kasuya, MD

Nagoya University, Japan

Sherif El-Khamisy, Ph D

Sheffield University, UK

Mohamed Ghanem, Ph D

Kafr Elshikh University, Egypt

Sayed Bakry, Ph D

Alazhar University, Egypt

Sameh Ali, Ph D

Nationa Liver Institute, Egypt

Gamal Badr, Ph D

Assuit University, Egypt

Nadia Hamdy, Pharm D

Ain Shams University, Egypt

\section{Editorial Board}

\section{Clinical studies}

Hesham Tawfik, MD

Tanta University, Egypt

Mohamed Attia, MD

Tanta University, Egypt

Mohamed Elshanshory, MD

Tanta University, Egypt

Essam Elshiekh, MD

Tanta Cancer Center, Egypt

Rasha Eraky, MD

Tanta University, Egypt

Shaima Abou-Kjatwa, MD

Tanta University, Egypt

Marcela Diaz, MD

Cleveland Clinic Foundation, USA

Mohamed Abou-El-Enein, MD

Charité Universitätsmedizin Berlin,

Germany
Alaa Eldin Almostafa, MD

McGill University, Canada

Olfat Gadallah, MD

Tanta University, Egypt

Nagla Sarhan, MD

Tanta University, Egypt

Naglaa Fathy, Pharm D

Zagazik University, Egypt

Mohamed Salama, MD

Mansoura University, Egypt

Mona Marie, MD

Alexandria University, Egypt

Preclinical studies

Mostafa El-Sheekh

Tanta University, Egypt

El-Refai Kenawy, Ph D

Tanta University, Egypt

Mohamed Noureldin, Ph D

Banaha University, Egypt

Yousry Albolkiny, Ph D

Tanta University, Egypt

Elsayed Salim, Ph D

Tanta University, Egypt

Shengdian Wang, Ph D

Chinese Academy of Sciences,

China

Sabry El Naggar, Ph D

Tnata Univesity, Egypr

Faris Alenzi, Ph D

Prince Sattam bin Abdulaziz

University, KSA

Ibrahim El-Sayed, Ph D

Menoufia University, Egypt

Tarek Aboul-Fadl, Ph D

Assiut University, Egypt

Rabab Khairat, Ph D

National Research Center,

Giza, Egypt

Wael Lotfy, Ph D

Alexandria University, Egypt

Ashraf Tabll, Ph D

National Research Center, Egypt

Nahla Shoukry, Ph D

Suez University, Egypt
Medhat Eldenary, Ph D

Tanta University, Egypt

Azza Hasan, Ph D

Menufia University, Egypt

Nanees Gamal Eldin, Ph D

Tanta University, Egypt

Mohamed Mansour, UK

Sabbah Hammoury, Ph D

Alexandria Ayadi Almostaqba

Oncology Hospital, Egypt

Nehal Aboulfotoh, Ph D

Zewail City for Science and

Technology, Cairo, Egypt

Amir Elkhami, Ph D

Galaxo, San Francisco, USA

Ahmed Alzohairy, Ph D

Zagazi University, Egypt

Wgady Khalil, Ph D

National Research Center, Egypt

Amr Amin, Ph D

United Arab Emirates

University, UAE

AbdelRahman Zekri, Ph D

National Cancer Institute, Egypt

Hussein Khamis, Ph D

Alexandria University, Egypt

Magdy Mahfouz, Ph D

Kafr Elsheikh University, Egypt

Ehab Elbedewey, Ph D

Tanta University, Egypt

Abeer Badr, Ph D

Cairo University, Egypt

Mamdooh Ghoneum, Ph D

Charles Drew University of

Medicine \& Science, USA

Haiam Abou Elela, Ph D

National Institute of Oceanography and Fisherie, Egypt

Maha EL-Demellawi, Ph D City for Scientific Research \&

Technology Applications, Egypt

Desouky Abd-El-Haleem, Ph D

City for Scientific Research \&

Technology Applications, Egypt 